\title{
UCRL-TR-228108-REV-1
}

TECHNICAL BASIS DOCUMENT FOR CRITERIA AND PROCESSES FOR THE CERTIFICATION OF

NON-RADIOACTIVE HAZARDOUS AND NON-HAZARDOUS WASTES

J. L. Dominick, R. F. Gaylord

June 29, 2007 
This document was prepared as an account of work sponsored by an agency of the United States Government. Neither the United States Government nor the University of California nor any of their employees, makes any warranty, express or implied, or assumes any legal liability or responsibility for the accuracy, completeness, or usefulness of any information, apparatus, product, or process disclosed, or represents that its use would not infringe privately owned rights. Reference herein to any specific commercial product, process, or service by trade name, trademark, manufacturer, or otherwise, does not necessarily constitute or imply its endorsement, recommendation, or favoring by the United States Government or the University of California. The views and opinions of authors expressed herein do not necessarily state or reflect those of the United States Government or the University of California, and shall not be used for advertising or product endorsement purposes.

This work was performed under the auspices of the U.S. Department of Energy by University of California, Lawrence Livermore National Laboratory under Contract W-7405-Eng-48. 


\section{TECHNICAL BASIS DOCUMENT FOR CRITERIA AND PROCESSES FOR THE CERTIFICATION OF NON-RADIOACTIVE HAZARDOUS AND NON-HAZARDOUS WASTES}

\section{INTRODUCTION}

This Technical Basis Document identifies how the values presented in the Criteria and Processes for the Certification of Non-Radioactive Hazardous and Non-Hazardous Wastes were derived.

The original moratorium document (UCRL-AR-109662) applied only to hazardous wastes generated in Radioactive Materials Management Areas (RMMAs) that were destined for off-site Treatment, Storage, and Disposal Facilities (TSDFs) that did not possess a radioactive materials license. Since its inception, the original moratorium document has become the de facto free-release procedure for potentially volumetrically contaminated materials of all varieties. This was promulgated in a February 4, 1992 memo from Jyle Lytle, Deputy Assistant Secretary for Waste Management, entitled Update: Moratorium on Shipment of Potentially Radioactive Hazardous and Toxic Wastes. In this memo, Ms. Lytle states, "While the moratorium does not apply to non-hazardous/non-TSCA solid wastes and non-waste materials, the same release criteria apply."

Over the past few years, a considerable quantity of data and operating experience has been developed, which has shown the limitations of UCRL-AR109662. The original Moratorium is out of date, and many of the organizations and procedures that it references are no longer in existence. In addition, the original document lacked sufficient detail to be used as an LLNL-wide procedure for free release, as it only addressed hazardous wastes. The original moratorium document also used highly optimistic Limits Of Sensitivity (LOSs) which were based on theoretically achievable minimum detectable activity (MDA) levels for various matrices. Years of operating experience has shown that these LOSs are simply not achievable for certain analyses in certain matrices, either due to limitations in sample size, or underestimates of the contribution of naturallyoccurring radioactive materials, resulting in the mis-characterization of samples of these matrices as radioactive, when no radioactivity was added by LLNL operations.

The new moratorium document updates the organizations involved in Moratorium Declarations, specifically addresses non-hazardous waste matrices, and allows for alternative types of analysis. The new moratorium document formalizes the process of release of potentially contaminated materials from radiological controls at LLNL. 


\section{ACRONYMS AND DEFINITIONS}

$\begin{array}{ll}\text { ASTM } & \text { American Society for Testing Materials } \\ \text { DOE } & \text { Department of Energy } \\ \text { EPA } & \text { Environmental Protection Agency } \\ \text { HEPA } & \text { High Efficiency Particulate Air } \\ \text { HPS } & \text { Health Physics Society } \\ \text { IAEA } & \text { International Atomic Energy Agency } \\ \text { LOS } & \text { Limit of Sensitivity } \\ \text { NRC } & \text { Nuclear Regulatory Commission } \\ \text { RHWM } & \text { Radioactive and Hazardous Waste Management }\end{array}$

$\mathrm{AL}$

MDA

MDC

NORM

NRA

RMA
Authorized Limit. A limit on the concentrations of residual radioactive material on the surfaces of or within property that has been derived consistent with the as low as reasonably achievable (ALARA) process, given the anticipated use of the property (either restricted or unrestricted), and that has been authorized by the Department of Energy to permit the release of the property from DOE control. (Reference 12).

Minimum Detectable Activity. For the purposes of this document, this is defined as Currie's $L_{D}$. A calculated value of the lowest activity that can be detected in a specific sample within a $95 \%$ confidence interval, given a specified background count rate, efficiency, chemical yield, and sample size.

Minimum Detectable Concentration. The MDA corrected for sample size.

Naturally-Occurring Radioactive Material. An example is K40 or Th-232 present in soil with no contribution from manmade sources.

No Radioactivity Added. A declaration for a sample that has met the moratorium requirements for release from radiological controls.

Radiological Materials Area. Any area within a controlled area, accessible to individuals, where items or containers of radioactive material exist and the total activity of radioactive material exceeds the applicable values provided in the ES\&H Manual, Document 20.2, Appendix E, Values for 
Establishing Sealed Radioactive Source Accountability and Radioactive Materials Posting and Labeling Requirements.

RMMA

Radioactive Materials Management Area. A workspace at LLNL in which the potential exists for contamination due to the presence of un-encapsulated or unconfined radioactive material, or an area that is exposed to beams or other sources of particles capable of causing activation.

SOW

Statement of Work. The Statement of Work for Analytical Services in Support of Lawrence Livermore National Laboratory.

\section{USE OF EXISTING REGULATIONS, ORDERS, AND STANDARDS}

The Performance Objective (Reference 5), states "A radioactive waste is any waste managed for its radioactive content which is not otherwise regulated for that radioactive content (e.g., regulated by Clean Air Act, etc.). If a material was received as nonradioactive, any resulting waste is not a radioactive waste if it meets the following conditions:

1. Contains no measurable increase in radioactivity (at a statistically defined confidence interval) above background in volume or bulk resulting from DOE operations except for wastes specifically exempted or excepted by the Environmental Protection Agency (EPA), DOE, or NRC regulations (e.g., 10 CFR 20.2005); and

2. Complies with the surface contamination requirements established in DOE Order 5400.5, 11.5.c. (1)". This portion of the PO allows invocation of other regulatory exemptions or exceptions with DOE approval (see \#3 below).

Wastes which satisfy the requirements of any of the following regulations and DOE Orders may be released from radiological controls.

1. Are of a form and history of use such that only surface contamination is possible, and that meet the surface contamination release limits of DOE Order 5400.5. Materials with known surface contamination shall be decontaminated to levels that are as low as is reasonably achievable.

2. Meet the City of Livermore Wastewater Discharge Permit for wastewaters sent to the sanitary sewer (Publicly Owned Treatment Works).

3. Meet radioactivity limits established by federal or state regulatory agencies (NRC, EPA and/or State Department of Health Services), and 
approved by DOE. See Memo from Nakahara to Crawford (1993), approving the use of 10 CFR 20.2005 (Reference 10).

Note that release of materials under these requirements is conducted under an Authorized Limit (AL) which is not the same as an NRA determination. Authorized Limits are authorized release limits for effluents containing residual radioactive material and require additional approvals by the receiving facility and the receiving facilities regulating agency. Before effluents leave the site under an Authorized Limit, the Authorized Limit must be approved and documented. Waste being transferred off-site under an Authorized Limit must be certified to the Authorized Limit under which they are being approved for release.

\section{REQUIREMENTS FOR ANALYSIS OF RADIOACTIVITY}

Sampling of bulk wastes shall be performed by technicians under the direction of the Radioactive and Hazardous Waste Management (RHWM) Sampling Team. Sampling activities shall be documented.

The process described in this document applies to a specific sample, not a waste stream. Application of the results of a given sample to multiple containers, or a complete waste stream, requires additional analysis and control which is beyond the scope of this document, but is provided in the waste specific characterization documentation package.

Analysis of bulk samples for radioactivity, for the purposes of this document, shall be performed by laboratories that can meet the Minimum Detectable Concentrations (MDCs) in Table 3. Off-site commercial analytical laboratories under contract with LLNL work to an approved Statement of Work for Analytical Services, which includes documented requirements for analytical methods and the associated detection limits. Samples may also be analyzed by on-site LLNL laboratories that operate under an approved quality assurance plan and operating procedures, and produce data that is scientifically valid, defensible, and of known precision and accuracy. All analyses are performed in accordance with established procedures from recognized organizations such as the American Society for Testing Materials (ASTM)/DOE/Environmental Protection Agency (EPA). Transmitted results shall include measured values, total propagated uncertainties, and sample-specific minimum detectable activity concentration values for each analysis. 


\section{ANALYSIS OF TRUE DETECTION LIMITS, AS COMPARED TO CALCULATED MORATORIUM LIMITS OF SENSITIVY (LOS)}

When the original Moratorium document was written in 1992, the LOSs for norad-added (NRA) were based on calculated limits of sensitivity for two types of radioactivity analysis: gas proportional counting for gross alpha and beta activity, and liquid scintillation counting for tritium. While there are a great deal of methods used in the calculation of detection limits, Currie's $L_{D}$ is probably the most commonly accepted method. This is defined as the true net signal level that may be expected a priori to lead to detection. In cases where the background count time is similar to the sample count time, this detection limit, often called Minimum Detectable Activity (MDA) is given at the $95 \%$ confidence limit as follows:

$$
M D A=\frac{2.71+4.66^{*} \sqrt{B}}{t^{*} E}
$$

$B=$ Total background counts

$t=$ Counting time in minutes

$E=$ Counting efficiency as a fraction. Note that this includes both counting efficiency, and the effects of sample self-absorption, if present.

When the MDA is divided by the sample size, the result is the MDC.

In order to determine the detection limits for these types of analyses, the following information is required:

- Count Time

- Background Count Rate

- Sample Size

- Detection Efficiency (including both detector-specific, and sample-specific effects)

The original LOSs were calculated for five matrices (aqueous, oils, solvents, coolants, and solids/sludges) using measured values for background count rates, but assumed values for sample size and detection efficiency. Both liquid scintillation counting and gas proportional counting have real physical limits on the sample size.

In liquid scintillation counting, overly large samples can result in immiscible sample-cocktail mixtures (the sample coming out of solution in the cocktail), or the cocktail becomes colored to the point where the detection efficiency drops to zero. In gas proportional counting, overly large sample sizes result in a high residual mass, and therefore a high attenuation of alpha particles. Operating experience from years of waste analysis has shown that the achievable counting 
sample size and detection efficiency were both lower than originally assumed, while the background count rates remained roughly constant. This means that the true achievable detection limits for waste samples are generally higher, sometimes by a large factor, than the original calculated moratorium LOSs.

The tables below show the LOSs limits in bold, along with the assumed sample sizes for each matrix in italics.

Table 1: Historical Calculated LLNL Moratorium Limits Of Sensitivity (LOSs) (from 1992 Moratorium document).

\begin{tabular}{|c|c|c|c|}
\hline Matrix & Gross $\alpha$ & Gross $\beta$ & Tritium \\
\hline Aqueous (AQ) & $\begin{array}{l}20 \mathrm{picoCi} / \mathrm{L} \\
25 \mathrm{~m} / \text { Sample } \\
100 \mathrm{~min} \text { count }\end{array}$ & $\begin{array}{c}60 \mathrm{picoCi} / \mathrm{L} \\
25 \mathrm{ml} \text { Sample } \\
100 \mathrm{~min} \text { count }\end{array}$ & $\begin{array}{c}3000 \mathrm{picoCi} / \mathrm{L} \\
5 \mathrm{ml} \text { Sample } \\
50 \mathrm{~min} \text { count }\end{array}$ \\
\hline Oil (OI) & $\begin{array}{c}500 \mathrm{picoCi} / \mathrm{L} \\
5 \mathrm{~m} / \text { Sample } \\
100 \mathrm{~min} \text { count }\end{array}$ & $\begin{array}{l}2000 \text { picoCi/L } \\
5 \mathrm{ml} \mathrm{Sample} \\
100 \text { min count }\end{array}$ & $\begin{array}{c}20,000 \mathrm{picoCi} / \mathrm{L} \\
0.1 \mathrm{ml} \text { Sample } \\
50 \mathrm{~min} \text { count }\end{array}$ \\
\hline Solids, Sludges (SO, SL) & $\begin{array}{c}1 \mathrm{picoCi} / \mathrm{gm} \\
0.5 \mathrm{gm} \text { Sample } \\
100 \mathrm{~min} \text { count }\end{array}$ & $\begin{array}{c}3 \mathrm{picoCi} / \mathrm{gm} \\
0.5 \mathrm{gm} \text { Sample } \\
100 \mathrm{~min} \text { count }\end{array}$ & $\begin{array}{l}5 \mathrm{picoCi} / \mathrm{gm} \\
1 \mathrm{gm} \text { Sample } \\
50 \mathrm{~min} \text { count }\end{array}$ \\
\hline Solvents (SV) & $\begin{array}{c}100 \mathrm{picoCi} / \mathrm{L} \\
5 \mathrm{~m} / \text { Sample } \\
100 \mathrm{~min} \text { count }\end{array}$ & $\begin{array}{c}300 \mathrm{picoCi} / \mathrm{L} \\
5 \mathrm{~m} / \text { Sample } \\
100 \mathrm{~min} \text { count }\end{array}$ & $\begin{array}{c}20,000 \mathrm{picoCi} / \mathrm{L} \\
0.1 \mathrm{ml} \text { Sample } \\
50 \mathrm{~min} \text { count }\end{array}$ \\
\hline Coolants (CO) & $\begin{array}{l}20 \mathrm{picoCi} / \mathrm{L} \\
25 \mathrm{~m} / \text { Sample } \\
100 \mathrm{~min} \text { count }\end{array}$ & $\begin{array}{c}60 \text { picoCi/L } \\
25 \mathrm{ml} \text { Sample } \\
100 \mathrm{~min} \text { count }\end{array}$ & $\begin{array}{c}20,000 \text { picoCi/L } \\
5 \mathrm{ml} \text { Sample } \\
0.1 \mathrm{ml} \text { Sample }\end{array}$ \\
\hline
\end{tabular}

In order to determine the true detection limits for real samples, a large sample of data from the past three years of waste analysis was analyzed to determine the average sample size, detection efficiency, and MDC for different matrices. These samples were analyzed at Chemistry and Material Science Environmental Services, LLNL's state-certified on-site environmental analysis lab. Table 2 summarizes the data from 106 Aqueous samples, 121 Solid/Sludge samples, 21 Oils, and 30 Solvents was analyzed. Results are discussed below. 
Aqueous Samples: Aqueous samples analyzed for gamma, alpha, and beta radioactivity show two distinct populations: a group of "clean matrix" retention tanks, berm waters and rain waters, which make up $64 \%$ of the total aqueous samples; and a group of "dirty matrix" mop waters, spent chemicals, and liquids high in dissolved solids which make up $36 \%$ of the aqueous samples. For the "clean matrix" samples, the average sample size was $26.5 \mathrm{mls}$, the average residual sample mass was $14 \mathrm{mg}$, and the average alpha and beta MDAs were 17 picoCi/L and 29 picoCi/L, respectively, in good agreement with the 1992 LOSs. In contrast, the "dirty matrix" group of samples had an average sample size of $1.1 \mathrm{mls}$ and a residual mass of $41 \mathrm{mg}$. For this group of samples, the average alpha detection limit was significantly higher at $1039 \mathrm{picoCi} / \mathrm{L}$, and the average beta MDA was 1411 picoCi/L. For tritium analysis for both groups of samples, the LOS sample size of $5 \mathrm{mls}$ and detection limit of $3000 \mathrm{picoCi} / \mathrm{L}$ were readily achievable.

Oil Samples: Oil samples analyzed for radioactivity had an average sample size of $0.2 \mathrm{mls}$, an average residual sample mass of $9 \mathrm{mg}$, and the average alpha and beta detection limits were $4937 \mathrm{picoCi} / \mathrm{L}$ and $9093 \mathrm{picoCi} / \mathrm{L}$, respectively. These values are significantly higher than the original moratorium limits. For tritium analysis, the average sample size was only $0.1 \mathrm{ml}$, and the counting efficiency was significantly less than the assumed value in the 1992 LOS, leading to a detection limit of $35,000 \mathrm{picoCi} / \mathrm{L}$.

Solid/Sludge Samples: Solid and sludge samples analyzed for radioactivity had an average sample size of 0.21 grams, and an average residual sample mass of $41 \mathrm{mg}$. The average alpha and beta detection limits were $5.8 \mathrm{picoCi} / \mathrm{gm}$ and 7.5 picoCi/gm, both of which are higher than the 1992 LOS. For tritium analysis, the 1-gram sample size resulting in a 5 picoCi/gm detection limit was readily achieved.

Solvent Samples: Solvent samples analyzed for radioactivity had an average sample size of $1.2 \mathrm{mls}$, an average residual sample mass of $30 \mathrm{mg}$, and the average alpha and beta detection limits were $1117 \mathrm{picoCi} / \mathrm{L}$ and $1647 \mathrm{picoCi} / \mathrm{L}$. These values are slightly higher than the original moratorium values. For tritium analysis, the average sample size was only $0.1 \mathrm{ml}$, and the counting efficiency was significantly less than the assumed value in the 1992 moratorium, leading to a detection limit of 35,000 picoCi/L.

Coolant Samples: For the collection period, very few coolant samples have been received for radioactivity analysis, as much of this waste stream is now recycled. Coolants that are analyzed are treated as "dirty matrix" aqueous samples, and have MDCs similar to this group. 
Table 2: Historically achieved Minimum Detectable Concentrations at LLNL.

\begin{tabular}{|c|c|c|c|}
\hline & \\
\hline & Gross $\alpha$ & Gross $\beta$ & Tritium \\
\hline \multirow{4}{*}{$\begin{array}{c}\text { Aqueous (AQ) } \\
\text { "Clean Matrix" } \\
\text { RT, Berms, Rain water }\end{array}$} & $17 \mathrm{picoCi} / \mathrm{L}$ & $29 \mathrm{picoCi} / \mathrm{L}$ & $3000 \mathrm{picoCi} / \mathrm{L}$ \\
\hline & $A v g=26.5 \mathrm{ml}$ Sample & $A v g=26.5 \mathrm{~m} /$ Sample & $5 \mathrm{ml}$ Sample \\
\hline & & & \\
\hline & 100 min count & 100 min count & 50 min count \\
\hline \multirow{4}{*}{$\begin{array}{c}\text { Aqueous (AQ) } \\
\text { "Dirty Matrix" } \\
\text { Spent chemicals, mop water } \\
\text { Coolants }\end{array}$} & $1039 \mathrm{picoCi} / \mathrm{L}$ & 1411 picoCi/L & $3000 \mathrm{picoCi} / \mathrm{L}$ \\
\hline & Avg=1.1 $\mathrm{m} /$ Sample & Avg=1.1 $\mathrm{m} /$ Sample & $5 \mathrm{~m} /$ Sample \\
\hline & & & \\
\hline & 100 min count & 100 min count & 50 min count \\
\hline \multirow[t]{4}{*}{ Oil (OI) } & $4937 \mathrm{picoCi} / \mathrm{L}$ & $9093 \mathrm{picoCi} / \mathrm{L}$ & $35,000 \mathrm{picoCi} / \mathrm{L}$ \\
\hline & Avg $=0.19 \mathrm{ml}$ Sample & $A v g=0.19 \mathrm{~m} /$ Sample & $0.1 \mathrm{~m} /$ Sample \\
\hline & S.D. $=( \pm 0.32 \mathrm{ml})$ & S.D. $=( \pm 0.32 \mathrm{ml})$ & \\
\hline & 100 min count & 100 min count & 50 min count \\
\hline \multirow[t]{4}{*}{ Solids, Sludges (SO, SL, XX) } & $5.8 \mathrm{picoCi} / \mathrm{gm}$ & $7.5 \mathrm{picoCi} / \mathrm{gm}$ & $5 \mathrm{picoCi} / \mathrm{gm}$ \\
\hline & $A v g=0.21 \mathrm{gm}$ Sample & $A v g=0.21 \mathrm{gm}$ Sample & $1 \mathrm{gm}$ Sample \\
\hline & S.D. $=( \pm 0.17 \mathrm{gm})$ & $S . D .=( \pm 0.17 \mathrm{gm})$ & \\
\hline & 100 min count & 100 min count & 50 min count \\
\hline \multirow[t]{4}{*}{ Solvents (SV) } & 1117 picoCi/L & $1647 \mathrm{picoCi} / \mathrm{L}$ & $35,000 \mathrm{picoCi} / \mathrm{L}$ \\
\hline & $A v g=1.2 \mathrm{gm}$ Sample & Avg=1.2 gm Sample & $0.1 \mathrm{ml}$ Sample \\
\hline & $S . D .=( \pm 0.76 \mathrm{gm})$ & $S . D .=( \pm 0.76 \mathrm{gm})$ & \\
\hline & 100 min count & 100 min count & 50 min count \\
\hline
\end{tabular}

See Appendices $A$ through $E$ for raw data.

Based on the above analysis, LLNL proposes to use the following MDCs as a guideline for acceptable analytical sensitivity. It should be noted that while these values are higher than the original (1992) Moratorium LOSs, this does not imply that higher levels of radioactivity are being released by LLNL. Since the numbers below are derived from the actual detection limits for real samples, this is not a 
true increase, but merely an adjustment of the sensitivity requirements to reflect MDCs that can actually be achieved with real samples.

Table 3. New Maximum MDC values for radioanalytical methods for LLNL samples.

\begin{tabular}{|c|c|c|c|}
\hline & Gross $\alpha$ & Gross $\beta$ & Tritium \\
\hline $\begin{array}{c}\text { Aqueous (AQ) } \\
\text { "Clean Matrix" } \\
\text { RT, Berms, Rain water }\end{array}$ & 20 picoCi/L & $\begin{array}{c}60 \mathrm{picoCi} / \mathrm{L} \\
100 \text { min count* }^{*}\end{array}$ & $3000 \mathrm{picoCi} / \mathrm{L}$ \\
\hline $\begin{array}{c}\text { Aqueous (AQ) } \\
\text { "Dirty Matrix" } \\
\text { Spent chemicals, mop water } \\
\text { Coolants }\end{array}$ & $\begin{array}{l}1500 \text { picoCi/L } \\
100 \text { min count* }\end{array}$ & $\begin{array}{l}2000 \text { picoCi/L } \\
100 \text { min count* }\end{array}$ & $3000 \mathrm{picoCi} / \mathrm{L}$ \\
\hline Oil (Ol) & $\begin{array}{l}5000 \text { picoCi/L } \\
100 \text { min count }^{*}\end{array}$ & $\begin{array}{c}10,000 \text { picoCi/L } \\
100 \text { min count }^{*}\end{array}$ & $\begin{array}{c}40,000 \text { picoCi/L } \\
50 \text { min count }^{*}\end{array}$ \\
\hline Solids, Sludges (SO, SL, XX) & $\begin{array}{l}10 \text { picoCi/gm } \\
100 \text { min count* }\end{array}$ & $\begin{array}{l}10 \text { picoCi/gm } \\
100 \text { min count* }\end{array}$ & $\begin{array}{l}5 \text { picoCi/gm } \\
50 \text { min count }^{*}\end{array}$ \\
\hline Solvents (SV) & $\begin{array}{l}1500 \text { picoCi/L } \\
100 \text { min count* }^{*}\end{array}$ & $\begin{array}{l}2000 \mathrm{picoCi} / \mathrm{L} \\
100 \mathrm{~min} \mathrm{count}^{*}\end{array}$ & $\begin{array}{c}40,000 \mathrm{picoCi} / \mathrm{L} \\
50 \mathrm{~min} \text { count }\end{array}$ \\
\hline
\end{tabular}

${ }^{*}$ Count times are estimates of the count times needed to achieve the required MDC, these specific times are not required. Achieving the MDC is required regardless of count time, some exceptions apply.

When radioanalytical data is available, the data will be compared to the Table 3 MDCs for that matrix (given in Table 3 above), the sample specific MDC, and any information regarding natural radioactivity present in the material. The authorized reviewer will evaluate this information and determine if the sample is to be managed as rad-added or non-radioactive. RHWM procedure WIC 148, Review of Radiochemical Data for Determination of Added Radioactivity (or equivalent), gives the requirements and steps taken to make this determination.

In order for a sample result to receive an NRA determination, the radiochemical method used to analyze the sample must achieve a sample MDC equal to or lower than the value in Table 1. For material with no detectable natural radioactivity, the sample results must be Non-Detect when compared to the sample specific MDC. For single results that are slightly above the sample specific MDC, the sample may be re-analyzed a second time to determine if the 
first analysis was a "false positive". If the subsequent analysis meets the target MDC and is a non-detect, a NRA determination may be assigned. If the subsequent analysis meets the target MDC and contains detectable activity greater than the sample specific MDC, the sample will be determined to have "Rad-Added".

Waste designated as "Rad Added" or "Containing Residual Radioactivity" may be managed through the AL process or managed as radioactive waste.

\section{COMPARISON OF LLNL MIXIMUM MDCS TO CURRENT EXEMPTION/CLEARANCE STANDARDS}

This document maintains the philosophy and approach of the original Moratorium, which defined "No Rad Added" material as being below detection limits for certain specified analytical methods. The analytical methods specified are sensitive, commonly available techniques, not heroic or research-oriented techniques. This approach may be termed "detection-limit based," as opposed to "dose-based" or "risk-based" approaches. Dose-based approaches commonly start with scenarios for waste disposal that include transportation, handling at waste disposal sites, and eventual transport of the radioactive materials to the environment where members of exposed groups are then exposed by both external and internal pathways. Computer models then give relationships between radioactivity of the waste for given isotopes, and dose to individuals in these exposed groups. A primary dose criterion is then chosen, which results in activity concentration limits for the chosen isotopes for the waste material that are protective of the primary dose criterion.

This dose-based method of deriving exemption/clearance standards for radioactivity in solid waste materials is used in two commonly cited and reviewed reports: the American National Standards Institute (ANSI), in collaboration with the Health Physics Society (HPS), released ANSI/HPS Standard N13.12 Surface and Volume Radioactivity Standards for Clearance in August of 1999 (Reference 13), while the International Atomic Energy Agency (IAEA), in 1996, issued an interim report entitled Clearance Levels for Radionuclides in Solid Materials: Application of Exemption Principles (Reference 14). Both of these reports only deal with solid materials disposed of to sanitary landfills, and both utilize a primary dose criterion of one mrem/year. Table 4 shows a comparison of the LLNL MDCs from this document with the ANSI and IAEA derived limits. 
Table 4. Comparison of LLNL MDCs with Exemption/Clearance Standards.

\begin{tabular}{|cccc|}
\hline Nuclide & ANSI standard & IAEA report & LLNL MDCs \\
\hline High-dose alpha emitter (eg. Pu-239) & $3 \mathrm{pCi} / \mathrm{gm}$ & $2.7-27 \mathrm{pCi} / \mathrm{gm}$ & $10 \mathrm{pCi} / \mathrm{gm}$ \\
High-dose beta emitter (eg. Cs-137) & $30 \mathrm{pCi} / \mathrm{gm}$ & $2.7-27 \mathrm{pCi} / \mathrm{gm}$ & $10 \mathrm{pCi} / \mathrm{gm}$ \\
Uranium (natural or depleted) & $30 \mathrm{pCi} / \mathrm{gm}$ & $2.7-27 \mathrm{pCi} / \mathrm{gm}$ & $10 \mathrm{pCi} / \mathrm{gm}$ \\
Tritium & $3000 \mathrm{pCi} / \mathrm{gm}$ & $\begin{array}{c}27,000-270,000 \\
\mathrm{pCi} / \mathrm{gm}\end{array}$ & $5 \mathrm{pCi} / \mathrm{gm}$ \\
\hline
\end{tabular}

It can be seen that the LLNL MDCs are substantially in agreement with currently accepted dose-based limits. It can further be seen that the LLNL MDCs are significantly below any dose-based limits for potentially tritium contaminated objects.

\section{SPECIAL CASE WASTES}

\section{Highly Toxic or Potentially Reactive Wastes}

If a sample is of such high toxicity and/or reactivity to preclude sample digestion for routine gross alpha/beta analysis via the gas proportional counting method due to increased personnel and infrastructure hazards, the sample may be analyzed via a combination of generator knowledge and other techniques, including liquid scintillation counting and/or gamma spectroscopy (in cases where all expected contaminants are gamma emitters). Liquid mercury and high explosive residues are examples of matrices commonly analyzed via this method.

Due to limitations in the sample aliquot size that may be safely processed for difficult matrices, the MDCs identified in Table 3 may not be achievable for some wastes, particularly those with large amounts of dissolved solids. In these cases, the actual sample-specific MDC will be used for determining whether the sample is radioactive or not. The limits for declaration of added radioactivity will default to the sample-specific MDC. Samples with an MDC greater than 100 times the Table 3 value for the matrix of concern will not be used for NRA determinations.

\section{Wastes Containing Naturally-Occurring Radioactive Materials (NORM)}


Many elements have naturally occurring primordial and/or cosmogenic radioisotopes, which contribute to the radioactivity in waste samples. The majority of these wastes do not contain "DOE added radioactivity." Examples of these include potassium chloride, a common salt substitute, which produces an easily measurable radiation field, or Be-7, a short-lived cosmogenic nuclide, in High Efficiency Particulate Air (HEPA) filters. NORM, which is incidental to the matrix being analyzed, may be subtracted from the total radioactivity and treated as background when making the determination of "DOE added radioactivity." One way to do this is to take the potassium concentration of the sample, from total metals analysis, and calculate the expected gross beta activity, then determine if the measured gross beta can be accounted for by the quantity of potassium. An alternative method is based on the analysis of "virgin" or "blank" materials, of the same or similar matrix to the waste, but known to be uncontaminated and determining the incidental natural occurring radioactivity for each matrix or material type.

For commonly-measured matrices where NORM or sample size make it difficult to determine whether radioactivity was added, such as mop water and machine oils, a blank material study may be performed by analyzing at least five samples from areas known to have never been associated with radioactive materials work. The average value and standard deviation of the gross alpha, beta, and tritium will be calculated for this set of samples. These results will be documented in a memo to file, attached to the requisition, and these limits will be used to determine if the waste contains added radioactivity.

Discarded "source material" as defined by the Atomic Energy Act, which includes uranium and thorium, or chemical compounds or commercial articles with identified uranium or thorium content are to be treated as radioactive regardless of how they were procured, stored, or handled. While specific exemptions may apply, the use of such exemptions must be approved by RHWM (with LSO concurrence), and documented on a case-by-case basis.

If DOE activities enhance, concentrate, or utilize the radiological attribute of NORM, the resulting material should be managed as material containing residual radioactivity per DOE $O 5400.5$ through an $\mathrm{AL}$ process or managed as radioactive waste per DOE 0435.1 . 


\section{Soils and Soil-Analogues}

Table 5. Historic Action Limits for Soils and Soil-analogues

\begin{tabular}{|c|c|}
\hline Criteria & Action Limit \\
\hline Gross Alpha & $\leq 15 \mathrm{pCi} / \mathrm{gm}$ \\
\hline Gross Beta & $\leq 25 \mathrm{pCi} / \mathrm{gm}$ \\
\hline Tritium & $\leq 5 \mathrm{pCi} / \mathrm{gm}$ \\
\hline
\end{tabular}

Soil values for Gross Alpha of $15 \mathrm{pCi} / \mathrm{g}$ and Gross Beta of $25 \mathrm{pCi} / \mathrm{g}$ are first identified by Bill Isherwood (Attachment 1 ) and are based upon analysis means plus two standard deviations for a population of 184 pre-construction samples from non-suspect sites in the Environmental Protection Department database. The attachment also identifies that known contamination areas will require special attention. This attachment makes no recommendation on tritium.

The Gross Alpha and Gross Beta results are endorsed in a memo from Howard L. Hall (Attachment 2) and a tritium value of $5 \mathrm{pCi} / \mathrm{g}$ in soil is put forth for unrestricted release based upon the LOS of tritium in soil. This memo also identifies that soil with a tritium concentration between 5-60 pCi/g may not be landfilled but may be reused on site. Soils with tritium concentrations exceeding $60 \mathrm{pCi} / \mathrm{g}$ must be handled as radioactive waste. The attachment also recommends bulk analysis of concrete and asphalt specifically for the identification of $\mathrm{Pu}$.

\section{Soils and Soil-Analogues Revisited}

The soil and soil analogue table was revised to clarify that these limits only apply to NORM in soils. The presence of man-made nuclides as determined through process knowledge or analytical results would preclude material from being released under the soil limits. Soil and soil-analogue matrices are defined as unconsolidated soil, gravel, asphalt, and concrete, with residual incidental construction debris (gypsum board, floor tiles, roofing materials, and construction wood). The release of materials using the values in Table 6 are based upon the assumption that the gross activity contribution is only from naturally occurring radionuclides and no DOE added or enhanced radioactivity is present. As identified in the following scenarios, appropriate documentation to support application of this assumption must be maintained. 
Table 6. New Action Limits/Release Limits for NORM in Soils and Soilanalogues (Volumetric)

\begin{tabular}{|c|c|}
\hline Criteria & $\begin{array}{c}\text { Action Limit } / \\
\text { Release Limit }\end{array}$ \\
\hline & \\
\hline Gross Alpha & $\leq 15 \mathrm{picoCi} / \mathrm{gm}$ \\
\hline Gross Beta & $\leq 25 \mathrm{picoCi} / \mathrm{gm}$ \\
\hline Tritium & $\leq \mathrm{MDC} @ 5 \mathrm{pCi} / \mathrm{g}^{*}$ \\
\hline
\end{tabular}

* Natural tritium levels in soil are well below the minimum detectable concentration of $5 \mathrm{pci} / \mathrm{g}$ of Table 1 . For soils with potential tritium contamination, the sample specific MDC must meet this limit and the sample results must be non-detect for an NRA determination. Tritium detected above the sample specific MDC will be declared "Rad Added" or "Containing Residual Radioactivity".

\section{Scenario 1: Non-suspect soils}

Non-suspect areas are areas where there is no history of use or contamination with dispersible radionuclides, especially transuranic nuclides. Identification and documentation of non-suspect areas is conducted and documented by ORAD through due diligence evaluations of projects prior to initiation of work. When documented, due diligence evaluations are considered equivalent to a generator NRA certification when coupled with supporting gross analysis. Under this scenario the gross alpha and beta analysis results are compared to Table 6 values. The evaluation of the data is documented and a "Rad Declaration" conducted.

\section{Scenario 2: Inconclusive soils}

For release of soil and soil-analogues from areas where due diligence is nonconclusive with respect to added radioactive contamination, gross alpha and gross beta results may be compared to the more restrictive Table 3 values (and be non-detect) or radionuclide speciation may be conducted to demonstrate only naturally occurring radionuclides and progeny in equilibrium are present. If radionuclide speciation indicates the presence of only naturally occurring radionuclides and progeny, the gross sample results may be compared to the Table 6 values above. The evaluation of the data is documented and a "Rad Declaration" conducted.

\section{Scenario 3: Suspect soils}

Samples from suspect areas that have a history or significant suspicion of having had spills or contamination incidents in the past shall undergo isotopic analysis for radionuclide speciation in addition to gross alpha and gross beta analysis. If radionuclide speciation indicates the presence of only naturally occurring radionuclides and progeny in equilibrium, the gross sample results may be 
compared to the Table 6 values above. The evaluation of the data is documented and a "Rad Declaration" conducted.

\section{Determination of added radioactivity for soils and soil analogues:}

Samples which meet the requirements of this section (meet Table 3 and are nondetect or measured gross activities meet Table 6 and no man made nuclides are expected/detected as documented on the due diligence certification) will receive an NRA determination. Samples which do not meet Table 6 or contain measurable man-made radioactivity will be determined to be "Rad-Added" or "Containing Residual Radioactivity".

\section{HEPA Filters}

HEPA filters are a particularly difficult matrix to safely analyze destructively. The level of rigor required for determining if a HEPA is to be managed as radioactive depends upon the level of generator knowledge available for the particular ventilation system with which the HEPA is associated. Filters with documented histories of use in facilities known to work only with natural and/or depleted uranium and/or thorium isotopes may be analyzed for radioactivity via a combination of swipe sampling, and gamma spectroscopy. If a swipe sample of the filter inlet shows no removable activity above ES\&H Manual Document 20.2, Appendix D limits, and a gamma count of the filter shows no detectable activity (with an MDA for 238-Uranium of 1 microCi or less), the filter will be declared non-radioactive. Filters from facilities that either have a poorly-known operating history, or have a history of using isotopes other than uranium or thorium may not be analyzed via this method, and shall either be sampled destructively, or declared radioactive.

\section{Surface Contamination Release As Authorized Limits}

Materials which only have the potential for surface contamination may be characterized for a Rad-Dec using swiping and direct survey techniques. The instrumentation used must be appropriate to the decay mode and energy of the isotopes being measured. Swipe and survey results must be documented and traceable to the material being released. Instrumentation used for swipe and survey must be sensitive enough to meet the limits presented in Table 7. 
UCRL-TR-228108-Rev 1

\section{Table 7. Authorized Release Limits for Surface Contaminated Wastes $\left(\mathrm{dpm} / 100 \mathrm{~cm}^{2}\right)^{\mathrm{a}, \mathrm{b}}$}

\begin{tabular}{|c|c|c|c|}
\hline Radionuclides $^{\mathrm{C}}$ & $\mathrm{Avg}^{d, e}$ & $\operatorname{Max}^{d, e}$ & Removable $^{f}$ \\
\hline $\begin{array}{l}\text { Group 1--Transuranics, },{ }^{125} \mathrm{I},{ }^{129} \mathrm{I},{ }^{227} \mathrm{Ac},{ }^{226} \mathrm{Ra},{ }^{228} \mathrm{Ra} \text {, } \\
{ }^{228} \mathrm{Th},{ }^{230} \mathrm{Th},{ }^{231} \mathrm{~Pa}\end{array}$ & 100 & 300 & 20 \\
\hline $\begin{array}{l}\text { Group 2--Th-natural, }{ }^{90} \mathrm{Sr},{ }^{126} \mathrm{I},{ }^{131} \mathrm{I},{ }^{133} \mathrm{I},{ }^{223} \mathrm{Ra},{ }^{224} \mathrm{Ra}, \\
{ }^{232} \mathrm{U},{ }^{232} \mathrm{Th}\end{array}$ & 1,000 & 3,000 & 200 \\
\hline $\begin{array}{l}\text { Group 3--U-natural, }{ }^{235} \mathrm{U},{ }^{238} \mathrm{U} \text {, associated decay } \\
\text { products, alpha emitters }\end{array}$ & 5,000 & 15,000 & 1,000 \\
\hline $\begin{array}{l}\text { Group } 4 \text {-- Beta-gamma emitters (radionuclides with } \\
\text { decay modes other than alpha emission or } \\
\text { spontaneous fission) except }{ }^{90} \mathrm{Sr} \text { and others noted } \\
\text { above }{ }^{g}\end{array}$ & 5,000 & 15,000 & 1,000 \\
\hline Tritium (applicable to surface and subsurface) ${ }^{h}$ & $\mathrm{~N} / \mathrm{A}$ & $\mathrm{N} / \mathrm{A}$ & 10,000 \\
\hline
\end{tabular}

a The values in this table (except for tritium) apply to radioactive material deposited on but not incorporated into the interior or matrix of the property. No generic concentration guidelines have been approved for release of material that has been contaminated in depth, such as activated material or smelted contaminated metals (e.g., radioactivity per unit volume or per unit mass). Authorized limits for residual radioactive material in volume must be approved separately.

$b \quad$ As used in this table, $\mathrm{dpm}$ (disintegrations per minute) means the rate of emission by radioactive material as determined by counts per minute measured by an appropriate detector for background, efficiency, and geometric factors associated with the instrumentation.

c Where surface contamination by both alpha-emitting and beta-gamma-emitting radionuclides exists, the limits established for alpha-emitting and beta-gamma-emitting radionuclides should apply independently.

$d$ Measurements of average contamination should not be averaged over an area of more than $1 \mathrm{~m} 2$. Where scanning surveys are not sufficient to detect levels in the table, static counting must be used to measure surface activity. Representative sampling (static counts on the areas) may be used to demonstrate by analyses of the static counting data. The maximum contamination level applies to an area of not more than $100 \mathrm{~cm}^{2}$.

e The average and maximum dose rates associated with surface contamination resulting from beta-gamma emitters should not exceed 0.2 millirad per hour $(\mathrm{mrad} / \mathrm{h})$ and $1.0 \mathrm{mrad} / \mathrm{h}$, respectively, at $1 \mathrm{~cm}$.

$f \quad$ The amount of removable material per $100 \mathrm{~cm}^{2}$ of surface area should be determined by wiping an area of that size with dry filter or soft absorbent paper, applying moderate pressure, and measuring the amount of radioactive material on the wiping with an appropriate instrument of known efficiency. When removable contamination of objects on surfaces of less than $100 \mathrm{~cm}^{2}$ is determined, the activity per unit area should be based on the actual area, and the entire surface should be wiped. It is not necessary to use wiping techniques to measure removable contamination levels if direct scan surveys indicate the total residual surface contamination levels are within the limits for removable contamination.

$g$ This category of radionuclides includes mixed fission products, including the ${ }^{90} \mathrm{Sr}$ that is present in them. It does not apply to ${ }^{90} \mathrm{Sr}$ that has been separated from the other fission products or mixtures where the "Sr has been enriched.

$h \quad$ Measurement should be conducted by a standard smear measurement but using a damp swipe or material that will readily absorb tritium, such as polystyrene foam. Property recently exposed or decontaminated should have measurements (smears) at regular time intervals to prevent a buildup of contamination over time. Because tritium typically penetrates material it contacts, the surface guidelines in group 4 do not apply to tritium. Measurements demonstrating compliance of the removable fraction of tritium on surfaces with this guideline are acceptable to ensure nonremovable fractions and residual tritium in mass will not cause exposures that exceed DOE dose limits and constraints. 


\section{Determination of added radioactivity for surface contaminated wastes:}

Swipe/survey results which meet Table 3 may be evaluated for a Rad-Dec. Documented swipe/survey results which are non-detect may be issued an NRA determination. Swipe/survey results which indicate the presence of measurable radioactivity above background will be issued a Rad-Dec of "Rad-Added" or "Contaminated with Residual Radioactivity".

Swipe/survey results declared as "Rad Added" or "Contaminated with Residual Radioactivity" may be managed through the Authorized Limit process or managed as radioactive waste.

Swipe/Survey results with measurable radioactivity above background but meeting Table 3 are considered "Rad-Added" or "Contaminated with Residual Radioactivity", but may not need to be managed as radioactive waste. These materials are considered to be contaminated with residual radioactive material and may be managed through the Authorized Limit process. DOE has authorized release of materials contaminated up to table 3 limits as an approved Authorized Limit (Reference 12). This DOE concurrence does not imply acceptance or concurrence on the limits by the receiving facility or the receiving facilities regulators.

\section{ATTACHMENTS}

1. Memorandum, From Bill Isherwood to Steve Hunt, Disposition of excess soil based on pre-construction soil sampling., August 26, 1991.

2. Environmental Protection Department, Memo from Howard L. Hall to Bill Isherwood, Report on the ad hoc committee on radiological analysis of soils and preconstruction debris., April 15, 1992.

\section{APPENDICES}

A. Aqueous - Clean Matrix (AQ-CM), Raw Data

B. Aqueous - Dirty matrix (AQ-DM), Raw Data

C. Oil (OI), Raw Data

D. Solids, Sludges (SO,SL), Raw Data

E. Solvents (SV), Raw Data

\section{REFERENCES}

1. Code of Federal Regulations, 10 CFR 835, Occupational Radiation Protection, Appendix D, Surface Contamination Values, latest revision. 
2. DOE Order 5400.5, Chg 2, Radiation Protection of the Public and the Environment, latest revision.

3. Lawrence Livermore National Laboratory. Criteria and Procedures for the Certification of Nonradioactive Hazardous Waste, UCRL-AR-109662.

4. $\quad$ Lawrence Livermore National Laboratory. ES\&H Manual, Document 20.2, LLNL Radiological Safety Program for Radioactive Materials.

5. U.S. Department of Energy (DOE) document, Performance Objective for Certification of Non-Radioactive Hazardous Waste (EM-30, 1995).

6. U.S. Department of Energy (DOE) document, Guide to Good Practice for Establishing Authorized Limits for the Release of Waste and Property Contaminated with Residual Radioactivity (March 1999).

7. Statement of Work for Analytical Services in Support of Lawrence Livermore National Laboratory and Lawrence Livermore National Laboratory, February 2004.

8. U.S. Department of Energy, Research and Development Laboratory Working Group (RADWG) Analytical Chemistry Laboratory Committee, Document No. DOE/CH-9403., September 14, 1993.

9. Environmental Protection Department, Environmental Monitoring and Analysis Division, Radiation Analytical Sciences Section, Memo from Howard Hall to Bill Isherwood, Subject: Report of the ad hoc committee on radiological analyses of soils and preconstruction debris, April 15, 1992.

10. U.S. Department of Energy, Memo from Daniel Nakahara to Richard Crawford, Use of Nuclear Regulatory Commission (NRC) Guidelines for Shipment of Hazardous Waste for Disposal, December 27, 1993.

11. Lawrence Livermore National Laboratory, Technical Basis Document for Criteria and Processes for the certification of Non-Radioactive Hazardous and Non-Hazardous Wastes, UCRL-IM-343724.

12. DOE G 441.1-XX, Control and Release of Property with Residual Radioactive Material, Issued by Andy Lawrence May 01, 2002.

13. ANSI/HPS N13.12-1999. Surface and Volume Radioactivity Standards for Clearance, 1999.

14. IAEA-TECDOC-855, Clearance levels for radionuclides in solid materials Application of Exemption Principles Interim report for comment, 1996. 
UCRL-TR-228108-Rev 1

Attachment 1 - Memorandum from Bill Isherwood to Steve Hunt, 8/26/91.

MEMORANDUM:

To: Steve Hunt

From: Bill Isherwood

Disposition of excess soil based on pre-construction soil sampling.

Background:

Unconsolidated materials, loosely referred to as soils, are generated during construction projects on-site, and in lesser amounts from the environmental sampling and restoration programs. These materials usually consist of unconsolidated sedimentary materials, but may also include debris such as asphalt or imported fill materials. Excess soils are frequently disposed of off-site.

The objectives of sampling and analysis of the soils are (a) to ensure proper disposal of materials, (b) to protect workers exposed to the materials, and (c) to determine the need for restoration activities. Only the disposal issue is considered in this memo, as the protection of workers and need for restoration are adequately dealt with elsewhere.

There are no current regulations that provide radiological

limits applicable to the disposal of soils. Laboratory policy, however, has been to perform radiological analyses on all soils prior to disposal; primarily to assure all parties that no materials from the Lab are placed in landfills in a manner that might subsequently be considered inappropriate or incur future liability (either legal of public relations). Disposal of soils that are not known or suspected to be contaminated are not controlled under RCRA. Disposal of the Environmental Restoration program's investigation-derived wastes (drill cuttings, core samples, and drilling mud) is covered by the Ground Water Project Quality Assurance Project Plan and Standard Operating Procedures, which have been reviewed and accepted by EPA and the California State agencies under their CERCLA oversight responsibilities.

DOE Order 5400.5 (IV, 4 a) provides guidance for residual concentrations of specific Ra and Th isotopes not to exceed $15 \mathrm{pCi} / \mathrm{g}$ in averaged soil more than $15 \mathrm{~cm}$ below the surface. This value should generally be comparable to a gross alpha value derived from our pre-construction soil samples, without identification of the responsible isotopes.

Historically, the actual decision on disposal of construction soils appears to have been made subjectively by the environmental 
UCRL-TR-228108-Rev 1

analyst in consultation with other experts in ORAD, based on gross alpha and gross beta counts, as well as chemical analyses performed off-site.

Problem:

Soils on- and off-site contain naturally occurring radioisotopes at levels generally exceeding the limits of sensitivity provided in LLNL's proposed Criteria and Procedures for the Identification and Management of Mixed Waste (Table 1, LLNL Criteria). A large increase in effort would be necessary to perform gamma spectrum and associated chemical analyses to verify individually that the observed activities result from natural (as opposed to "added") radioactivity and the increased workload is beyond the capabilities of LLNL at this time.

Historically, Hazards Control has provided some support in both sample preparation and counting. (By far, the most time consuming part of the process is the sample preparation.) $\mathrm{HC}$ does not see the analysis of these samples as within their mission and has minimal resources. This has resulted in low priority being given to such work, lack of committment to turn-around times, and an expressed desire to not perform this work in the future.

The use of off-site contract laboratories has had a checkered past. TMA Norcal is under contract to EPD, but has not been able to provide consistent turn-around times less than 90 days, although as of August 23, they claim 8 weeks (56 days). Their standard LOS's are also above those of our LLNL labs. A New Mexico lab, CEP, has been contacted and claims a 21 day standard turn-around, with a rush of 7 days available for a 50\% surcharge. Their LOS's compare favorably with LLNL's. Although CEP is not under direct contract to LLNL, they do sub-contract to ETC, whose LLNL contract has just been reinstated.

A compounding factor in the length of time required to get results from off-site laboratories has been the protocols associated with "special nuclear handling" procedures used for sending samples to a laboratory for radiological analyses. Reportedly, several weeks have often been lost in getting the samples off the LLNL site.

The environmental analysts estimate an average of about 25 pre-construction soil samples per month are generated by the current procedures, but they may come sporadically in batches of 60 or 80. The EPD analytical laboratories (EAS and RAS) must now give first priority to compliance sample analysis for HWM, leaving no resources to analyze pre-construction soil samples. Failure to 
UCRL-TR-228108-Rev 1

provide timely decisions on soil disposal has the potential to delay major construction projects and jeopardize funding.

Natural Background Radioactivity

EPD's database of soil analyses has 184 results for gross alpha and gross beta. None of these samples comes from an area suspected to have contamination with a radioisotope which would elevate the gross alpha or beta activity nor, on cursory examination, appear to be outliers of a normal (log-normal) distribution of results. The averages, standard deviations, and LOS in the LLNL Criteria are as follows:

$\begin{array}{lccc} & \text { Average } & \text { Standard Deviation } & \text { LOS } \\ \text { gross alpha } & 5.5 \mathrm{pCi} / \mathrm{g} & 4.6 \mathrm{pCi} / \mathrm{g} & 1 \mathrm{pCi} / \mathrm{g} \\ \text { gross beta } & 14 \mathrm{pCi} / \mathrm{g} & 5.8 \mathrm{pCi} / \mathrm{g} & 3 \mathrm{pCi} / \mathrm{g}\end{array}$

(These vary slightly if done after log transformed.)

There are three areas on-site where tritium may have been added to the environment by specific LLNL activities: (1) near the solar evaporation ponds which were located near the present Building 5475, (2) surrounding the leaked tank at Building 292, and (3) by the waste handling facilities at Building 514 . Other detectable levels of tritium activity in the LLNL vicinity could be the result of rain-out from LLNL's and SNL's atmospheric emissions.

By far the highest tritium activities measured in on-site soils have been at the Building 292 leak area, where 200,000,000 pCi/L of soil moisture was detected. If this concentration were maintained over a volume of one cubic meter, it would translate to 0.05 Ci/cubic meter; still far below the limit of $40 \mathrm{Ci} / \mathrm{cubic}$ meter given in $10 \mathrm{CFR}$, section 61.55, for classification as a Class A solid waste. The background for on-site soil has been estimated to average about $350 \mathrm{pCi} / \mathrm{L}$ of soil moisture (approximately $0.03 \mathrm{pCi} / \mathrm{g}$ of soil), which is below the LLNL LOS of $15 \mathrm{pCi} / \mathrm{g}$.

\section{Discussion:}

None of the soil in questions is derived from an RMMA nor, except for three relatively well defined areas, is there any reason to believe that radioactivity has been added by LLNL activities. I have not discovered any cases where pre-construction soil analyses have yielded results which have in the past precluded off-site disposal of materials. Without explicit regulatory guidance and with clear indications that no health threat is involved, it appears reasonable to use background data to judge whether soils from on-site can be co-mingled with soils from other sources in public landfills without being liable for environmental insult. 
With the site characterization now available from the Lab's Environmental Restoration Program and previous pre-construction sampling, much of the site may be adequately sampled already. Materials from areas of known contamination or potentially leaked underground tanks, of course, continue to require special attention.

Recommendation:

(1) Minimize new pre-construction sampling by utilizing preexisting data and historical information about the area in question.

(2) Sample as early in the planning process as possible, to avoid last minute rush analysis requests. This should be possible for large jobs by triggering a request at the time NEPA documentation is being prepared. For small jobs, which may have short lead times, adequate space should be planned to store construction soils until analyses are complete.

(3) The Sampling Team at EAS should become the central clearing house for directing samples to the appropriate laboratory for sample prep and analysis. Environmental analysts with ORAD continue to be the liaison with the programs and will be responsible for "pre-screening" of the work site with a micro-R meter. The analysts will work closely with the Sampling Team Leader.

(4) Whenever on-site laboratories cannot commit to less than a 4 week turn-around, the Sampling Team Leader shall direct samples to off-site laboratories capable of meeting the specific analytical needs. In general this will require gross alpha, gross beta, and tritium analyses. LLNL should establish direct contracts with at least one laboratory capable of meeting these needs (e.g. CEP). Until such direct contract is in place, the ETC contract should be utilized, allowing them to sub-contract, as necessary.

(5) Special nuclear handling protocols should not be invoked, unless there is a specific reason to believe that the sample is contaminated with radionuclides. This should expedite shipping.

(6) The criteria for off-site disposal should be based on historical background activities. Specifically, I recommend that values of gross alpha less than $15 \mathrm{pCi} / \mathrm{g}$ and gross beta less than 25 $\mathrm{pCi} / \mathrm{g}$ be cleared for unrestricted off-site disposal, as being within the natural range of radioactivity, without further requirement for gamma spectrum and chemical analyses to verify the primordial content. (These values are the means, plus two standard deviations, of the EPD database results.) Use of these values appears to be consistent with the approach used in DOE Order 5400.5 .

(7) If the limits above are exceeded (and confirmed by reanalysis if warranted), then the same procedures as given in the 
UCRL-TR-228108-Rev 1

Criteria and Procedures for the Identification and Management of Mixed Waste would apply. 


\section{Attachment 2 - Memorandum from Howard Hall to Bill Isherwood, 4/15/92.}

\author{
Interdepartmental Letterhead \\ Mail Station L-233 \\ Ext. 2-7446
}

\author{
ENVIRONMENTAL PROTECTION DEPARTMENT \\ Environmental Monitoring \& Analysis Div. \\ Radiation Analytical Sciences Section
}

To: $\quad$ Bill Isherwood, EMAD Division Leader

From: $\quad$ Howard L. Hall, RAS Section Leader

Date: $\quad$ April 15, 1992

Subject: $\quad$ Report of the ad hoc committee on radiological analyses of soils and preconstruction debris.

As was requested in Steve Hunt's memo to you dated 9/9/91, a committee was formed to examine the issue of radiological analyses of soil and construction debris. The charge to the committee was to technically review the procedures proposed in your memo to Steve Hunt dated 8/26/91 and to obtain concurrence from RAS, Health Physics, and Environmental Operations Group. The members of the committee were:

$\begin{array}{ll}\text { Howard Hall } & \text { RAS, Chair } \\ \text { Price Russ } & \text { EAS } \\ \text { Joy Hirabayashi } & \text { EOG } \\ \text { Rich Michalik } & \text { EOG } \\ \text { Dave Myers } & \text { Health Physics } \\ \text { Dorothy Bishop } & \text { ERD } \\ \text { Amelia Hagen } & \text { HWM }\end{array}$

The committee addressed two issues: first, we technically reviewed the proposed action levels; and second, we examined the issue of what construction debris should be sampled for bulk analyses. The recommendations of the committee are given below.

Propused action levels:

The values proposed were:

$\begin{array}{ll}\text { gross alpha: } & 15 \mathrm{pCi} / \mathrm{g} \text { soil } \\ \text { gross beta: } & 25 \mathrm{pCi} / \mathrm{g} \text { soil } \\ \text { tritium: } & \text { No recommendation }\end{array}$

The committee concurs with the recommendations for gross alpha and gross beta. Furthermore, the committee recommends a two-tiered action level for tritium in soils. This recommendation is:

$\frac{\text { Tritium Conc. (pCi/g soil) }}{<5}$
$5-60$
$>60$

Disposal

No restrictions - may be landfilled off-site

Cannot be landfilled, but may be re-used on-site

Soil must be treated as radioactive waste

\section{LAWRENCE LIVERMORE NATIONAL LABORATORY}


We based these values on the RAS LOS for tritium in soil ( $5 \mathrm{pCi} / \mathrm{g})$ and the proposed drinking water limit from the EPA. We confirmed that these values are consistent with the values used by ERD for management decisions. The committee recommends that the value be measured as the concentration in the soil, not in the soil moisture. This should expedite analysis.

\section{Samples to be analyzed by bulk methods:}

Cement and asphalt are difficult to analyze by bulk methods due to the intractability of the sample matrix. The committee discussed other methods that might be used for analysis of these materials. Field counting is not sensitive enough to meet the above action levels. Swiping may reach the above levels, however, we had a number of reservations about the removal efficiency of swipes on concrete and other porous, ion-exchanging media. Lowlevel gamma counting would not detect $\mathrm{Pu}$ at the action levels, whereas gross alpha would. We believe failure to perform measurements that would detect Pu would compromise the legitimacy of analysis. Our recommendation is that these samples be analyzed by bulk methods and that the appropriate resources to perform these measurements be allocated.

Howard L. Hall
Howard L. Hall, Chair
Ad hoc committee on radiological analyses
of soils and preconstruction debris.

\section{Distribution:}

Howard Hall

Price Russ

Joy Hirabayashi

Rich Michalik

Dave Myers

Dorothy Bishop

Amelia Hagen

Keith Gilbert

Susi Jackson

Fred Hoffman

Harry Galles 


\section{Appendix A - Aqueous Clean Matrix}

Aqueous - Clean Matrix (AQ-CM)

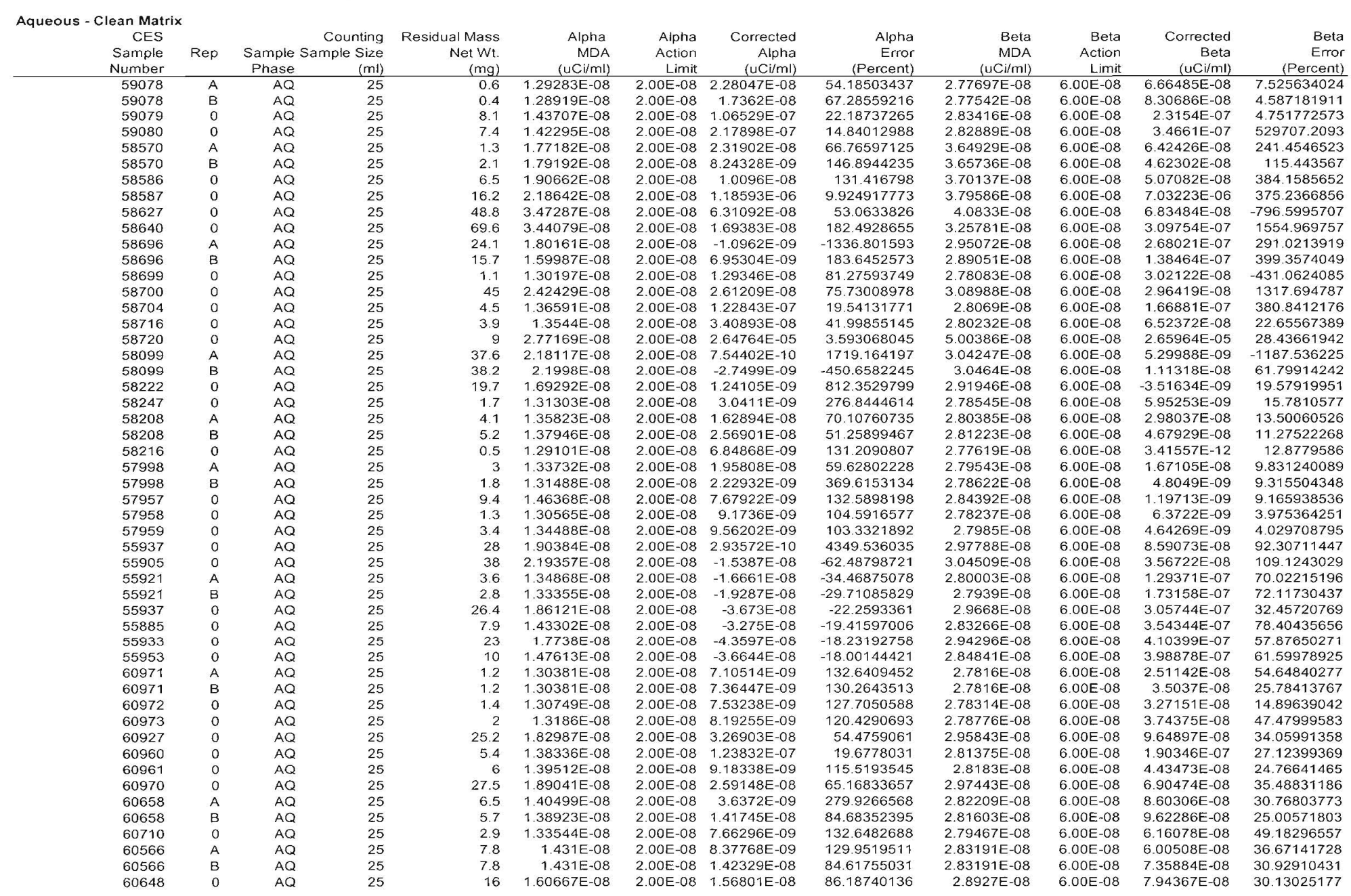


Aqueous - Clean Matrix (AQ-CM)

\begin{tabular}{|c|c|c|c|c|c|c|c|c|c|c|c|c|}
\hline \multicolumn{13}{|c|}{ Aqueous - Clean Matrix } \\
\hline CES & & & Counting & Residual Mass & Alpha & Alpha & Corrected & Alpha & Beta & Beta & Corrected & Beta \\
\hline $\begin{array}{l}\text { Sample } \\
\text { Number }\end{array}$ & Rep & $\begin{array}{c}\text { Sample } S \\
\text { Phase }\end{array}$ & $\begin{array}{r}\text { Sample Size } \\
(\mathrm{ml})\end{array}$ & Net Wt. & $\begin{array}{r}\mathrm{MDA} \\
(\mathrm{uCi} / \mathrm{ml})\end{array}$ & $\begin{array}{c}\text { Action } \\
\text { Limit }\end{array}$ & $\begin{array}{r}\text { Alpha } \\
(u \text { Ci/ml) }\end{array}$ & $\begin{array}{r}\text { Error } \\
\text { (Percent) }\end{array}$ & $\begin{array}{r}\mathrm{MDA} \\
(\mathrm{uCi} / \mathrm{ml})\end{array}$ & $\begin{array}{c}\text { Action } \\
\text { Limit }\end{array}$ & $\begin{array}{r}\text { Beta } \\
(\mathrm{uCi} / \mathrm{ml})\end{array}$ & $\begin{array}{r}\text { Error } \\
\text { Percent) }\end{array}$ \\
\hline 60489 & $\bar{A}$ & $A Q$ & 25 & 0.4 & $1.28919 \mathrm{E}-08$ & $2.00 \mathrm{E}-08$ & $1.26625 \mathrm{E}-08$ & 82.21967894 & $2.77542 \mathrm{E}-08$ & $\begin{array}{r}6.00 \mathrm{E}-08 \mathrm{I} \\
\end{array}$ & $\frac{(1 / 24)}{3.24883 \mathrm{E}-08}$ & $\begin{array}{r}\text { (Percent) } \\
3.592420152\end{array}$ \\
\hline 60489 & B & $A Q$ & 25 & 0.3 & 1.28737E-08 & $2.00 \mathrm{E}-08$ & $-1.8799 E-09$ & -398.7608364 & $2.77465 \mathrm{E}-08$ & $6.00 \mathrm{E}-08$ & $2.8195 \mathrm{E}-08$ & 2956835709 \\
\hline 60444 & 0 & $A Q$ & 25 & 26.6 & $1.86648 \mathrm{E}-08$ & $2.00 \mathrm{E}-08$ & 1.27776E-08 & 119.6851948 & $2.96819 E-08$ & $6.00 E-08$ & 1.17179E-07 & 61.85982252 \\
\hline 58640 & 0 & $\mathrm{AQ}$ & 25 & 69.6 & $3.44 \mathrm{E}-08$ & 1.694E-08 & 182.4928655 & & $3.26 \mathrm{E}-08$ & $3.0975 \mathrm{E}-07$ & 13.46157289 & \\
\hline 58696 & A & $\mathrm{AQ}$ & 25 & 24.1 & $1.80 \mathrm{E}-08$ & $-1.096 \mathrm{E}-09$ & -1336.80159 & & 2.95E-08 & $2.6802 \mathrm{E}-07$ & 12.21468859 & \\
\hline 58696 & B & $A Q$ & 25 & 15.7 & $1.60 \mathrm{E}-08$ & 6.953E-09 & 183.6452573 & & $2.89 \mathrm{E}-08$ & $1.3846 \mathrm{E}-07$ & 19.08218807 & \\
\hline 58699 & 0 & $A Q$ & 25 & 1.1 & $1.30 \mathrm{E}-08$ & 1.293E-08 & 81.27593749 & & $2.78 \mathrm{E}-08$ & $3.0212 \mathrm{E}-08$ & 66.19298561 & \\
\hline 58700 & 0 & $A Q$ & 25 & 45 & $2.42 \mathrm{E}-08$ & $2.612 \mathrm{E}-08$ & 75.73008978 & & 3.09E-08 & $2.9642 \mathrm{E}-08$ & 74.30712698 & \\
\hline 58704 & 0 & $A Q$ & 25 & 4.5 & $1.37 \mathrm{E}-08$ & 1.228E-07 & 19.54131771 & & $2.81 \mathrm{E}-08$ & $1.6688 \mathrm{E}-07$ & 16.34475202 & \\
\hline 58716 & 0 & $A Q$ & 25 & 3.9 & 1.35E-08 & 3.409E-08 & 41.99855145 & & $2.80 \mathrm{E}-08$ & $6.5237 \mathrm{E}-08$ & 33.94837015 & \\
\hline 58720 & 0 & $\mathrm{AQ}$ & 25 & 9 & $2.77 \mathrm{E}-08$ & $2.648 \mathrm{E}-05$ & 3.593068045 & & $5.00 E-08$ & $2.6596 \mathrm{E}-05$ & 2.233703766 & \\
\hline 66668 & A & $\mathrm{AQ}$ & 30 & 47.8 & $2.10275 \mathrm{E}-08$ & $2.00 \mathrm{E}-08$ & $2.96683 \mathrm{E}-06$ & 7.789466036 & $2.58938 \mathrm{E}-08$ & $6.00 \mathrm{E}-08$ & $3.70682 E-06$ & 70.27912071 \\
\hline 66668 & B & $A Q$ & 30 & 48 & $2.10877 \mathrm{E}-08$ & $2.00 \mathrm{E}-08$ & 2.69751E-06 & 7.965493984 & $2.59041 \mathrm{E}-08$ & $6.00 \mathrm{E}-08$ & $3.47645 \mathrm{E}-06$ & 22.18480888 \\
\hline 66071 & A & $A Q$ & 30 & 3.6 & $1.1239 \mathrm{E}-08$ & $2.00 E-08$ & 4.82484E-09 & 162.2757322 & $2.33336 \mathrm{E}-08$ & $6.00 E-08$ & 1.76703E-08 & 36.75141426 \\
\hline 66071 & B & $A Q$ & 30 & 3.4 & $1.12074 \mathrm{E}-08$ & $2.00 E-08$ & $2.72455 \mathrm{E}$ & 269.7444202 & $2.33208 \mathrm{E}-08$ & $6.00 E-08$ & $1.47748 \mathrm{E}-08$ & 2.335596676 \\
\hline 66073 & & $A Q$ & 30 & 5.3 & $1.15118 \mathrm{E}-08$ & $2.00 E-08$ & 1.30917E-08 & 72.94792931 & $2.34416 \mathrm{E}-08$ & $6.00 \mathrm{E}-08$ & 2.39505E-08 & 2.29704518 \\
\hline 57917 & 0 & $A Q$ & 100 & 6.1 & $3.49272 E-09$ & $2.00 \mathrm{E}-08$ & $-5.8961 \mathrm{E}-10$ & -324.955427 & $7.04765 \mathrm{E}-09$ & $6.00 \mathrm{E}-08$ & $1.24439 \mathrm{E}-09$ & 2.304180235 \\
\hline AQ-CM Average: & & & 26.470588 & 14.13088235 & $1.66072 \mathrm{E}-08$ & & & & 2.93778 & & & \\
\hline Std. Dev: & & & 9.1447246 & 9.144724584 & 9.144724584 & & & & 9.144724584 & & & \\
\hline AQ-CM Average: & & & & & 16.60721857 & $\mathrm{Ci} / \mathrm{L}$ & & & 29.37781851 & $\mathrm{Ci} / \mathrm{L}$ & & \\
\hline
\end{tabular}

Total 68 Samples Sample Size $(\mathrm{ml})$

68

Data Provided by Reggie Gaylord 9/21/06

Sample sizes for AQ-CM are all $>20 \mathrm{ml}$. 


\section{Appendix B - Aqueous Dirty Matrix}

Aqueous - Dirty Matrix (AQ-DM)

\begin{tabular}{|c|c|c|c|c|c|c|c|c|c|c|c|c|}
\hline \multicolumn{13}{|c|}{$\begin{array}{l}\text { Aqueous - Dirty Matrix } \\
\text { CES }\end{array}$} \\
\hline $\begin{array}{r}\text { CES } \\
\text { Sample }\end{array}$ & Rep & & $\begin{array}{r}\text { Counting } \\
\text { Sample Size }\end{array}$ & $\begin{array}{l}\text { Residual Mass } \\
\text { Net We. }\end{array}$ & $\begin{array}{l}\text { Alpha } \\
\text { MDA }\end{array}$ & $\begin{array}{l}\text { Alpha } \\
\text { Action }\end{array}$ & $\begin{array}{r}\text { Corrected } \\
\text { Alpha result }\end{array}$ & $\begin{array}{l}\text { Alpha } \\
\text { Error }\end{array}$ & $\begin{array}{l}\text { Beta } \\
\text { MDA }\end{array}$ & $\begin{array}{r}\text { Beta } \\
\text { Action }\end{array}$ & $\begin{array}{l}\text { Corrected } \\
\text { Beta result }\end{array}$ & $\begin{array}{l}\text { Beta } \\
\text { Error }\end{array}$ \\
\hline $\begin{array}{l}\text { Uumber } \\
5707\end{array}$ & & Phase & $\left.(m)^{2}\right)$ & $(\mathrm{mg})$ & (uCi/ml) & Limit & (uCi/ml) & (Percent) & (uci/mi) & Limit & (uCi/ml) & (Percent) \\
\hline $\begin{array}{l}58787 \\
62088\end{array}$ & $\begin{array}{l}0 \\
0 \\
0\end{array}$ & $\begin{array}{l}A Q \\
M O P\end{array}$ & $\begin{array}{l}33333 \\
0.199\end{array}$ & $\begin{array}{l}17.8 \\
622\end{array}$ & $\begin{array}{l}3.80322 E-06 \\
3.71527 \mathrm{E}-06\end{array}$ & $\begin{array}{l}2.00 E-08 \\
2.00 \mathrm{E}-08\end{array}$ & $\begin{array}{l}6.18347 \mathrm{E}-06 \\
1.57949 \mathrm{E}-06\end{array}$ & $\begin{array}{l}56.82612466 \\
163.9421164\end{array}$ & $\begin{array}{l}6.70562 \mathrm{E}-06 \\
5.49297 \mathrm{E}-06\end{array}$ & $\begin{array}{l}6.00 E-08 \\
6.00 E-08\end{array}$ & $\begin{array}{l}1.28672 \mathrm{E}-05 \\
-4.4584 \mathrm{E}-07\end{array}$ & $\begin{array}{r}3.5050314788 \\
3.11897692\end{array}$ \\
\hline $\begin{array}{l}620817 \\
58217\end{array}$ & 0 & $A Q$ & 0.2 & $\begin{array}{l}02.2 \\
78\end{array}$ & $4.65929 \mathrm{E}-06$ & $2.00 E-08$ & $\begin{array}{l}1.58949 \mathrm{E}-00 \\
7.30281 \mathrm{E}-07\end{array}$ & 395.2294149 & $4.49863 E-06$ & $\begin{array}{l}.0 .00 \mathrm{E}-08 \\
6.00-08\end{array}$ & $\begin{array}{l}-4.458 \mathrm{E}-0 \\
1.14989 \mathrm{E}-06\end{array}$ & $\begin{array}{r}3.1796964 \\
40.00579664\end{array}$ \\
\hline 58215 & o & $A Q$ & 0.25 & 47.5 & $2.51251 \mathrm{E}-06$ & $2.00 E-08$ & $4.73398 \mathrm{E}-05$ & 16.28619875 & $3.10541 \mathrm{E}-06$ & 6.00E-08 & 0.000216829 & 39.50800811 \\
\hline 58213 & 0 & $A Q$ & 0.266666667 & 55.7 & $2.64769 \mathrm{E}-06$ & $2.00 \mathrm{E}-08$ & $2.96282 \mathrm{E}-05$ & 20.85894019 & $2.96209 \mathrm{E}-06$ & 6.00E-08 & 0.000107695 & 33.081824 \\
\hline 58214 & 0 & $A Q$ & 0.266666667 & 52.6 & $2.53353 \mathrm{E}-06$ & $2.00 E-08$ & $5.17238 \mathrm{E}-05$ & 16.14685138 & & & 39 & \\
\hline 58210 & 0 & $A Q$ & 0.333333333 & 69.8 & $2.58793 \mathrm{E}-06$ & $2.00 E-08$ & 2.94911E-05 & 23.27255622 & $2 E-06$ & & 00139029 & 4789044 \\
\hline 62084 & 0 & MOP & & 15.7 & 7.61427E-07 & $2.00 E-08$ & 2.68521E-05 & 10.97572237 & $1.96964 \mathrm{E}-06$ & $6.00 \mathrm{E}-08$ & 0.000125536 & 10.02433635 \\
\hline 62085 & $\begin{array}{l}0 \\
0\end{array}$ & MOP & 0.5 & 14.8 & $7.51785 E-07$ & $2.00 \mathrm{E}-08$ & $2.11967 \mathrm{E}-05$ & $\begin{array}{l}11.98365285 \\
1\end{array}$ & $1.96514 \mathrm{E}-06$ & 6.00E-08 & 8.3904E-05 & 40.31175065 \\
\hline 62087 & 0 & Mop & 0.5 & 61.3 & $1.459871 E-06$ & $2,00 E=08$ & $6.91321 \mathrm{E}-0 \mathrm{f}$ & 150.2485043 & $2.18179 \mathrm{E}-06$ & & 9.1173 & 52.99489426 \\
\hline $\begin{array}{l}62089 \\
62090\end{array}$ & 0 & & 0.5 & 35 & $1.00132 \mathrm{E}-06$ & & 4.49752E-07 & 156.3057956 & 16 & & & 9.51746193 \\
\hline $\begin{array}{l}62090 \\
62092\end{array}$ & 0 & MOP & $\begin{array}{l}0.5 \\
0.5\end{array}$ & $\begin{array}{l}40.2 \\
60.3\end{array}$ & $1.07845 \mathrm{E}-06$ & $2.00 E-08$ & $\begin{array}{l}5.65254 \mathrm{E}-07 \\
7\end{array}$ & $\begin{array}{l}139.26524202 \\
13.272\end{array}$ & 2.08505E-06 & 6.00E-08 & 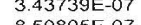 & 2.39156272 \\
\hline $\begin{array}{l}62092 \\
57891\end{array}$ & & & 1 & $\begin{array}{l}63.7 \\
73.7\end{array}$ & $\begin{array}{l}1.43912 E-06 \\
8.9633 E-07\end{array}$ & $\begin{array}{l}2.00 \mathrm{E}-08 \\
2.00 \mathrm{E}-08\end{array}$ & $5.92645 \mathrm{E}-07$ & 125.17251879 & $2.1685 E-06$ & (.000 & P. & $\begin{array}{r}42.15727651 \\
1346157280\end{array}$ \\
\hline 57892 & & & 1 & 75.4 & $9100 \quad-90$ & $\begin{array}{l}2.00 E-08 \\
200 E-08\end{array}$ & -7.459 & $\begin{array}{l}115.04698 \\
6726585487\end{array}$ & 0.2. & 然 & 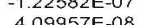 & $\begin{array}{r}13.46157289 \\
12.21468859\end{array}$ \\
\hline 57911 & & $A Q$ & 1 & 73.8 & $897182 \mathrm{E}-07$ & $200 \mathrm{E}-08$ & $\begin{array}{l}1.53056-0.8 \\
318658 \mathrm{E}-8\end{array}$ & 1661074009 & $8821244 \mathrm{E}-07$ & $\begin{array}{l}600-08 \\
600-08\end{array}$ & 143371E & $\begin{array}{l}72.21468859 \\
1908218807\end{array}$ \\
\hline 65985 & 0 & $A Q$ & 1 & 14.8 & $3.94915 \mathrm{E}-07$ & $2.00 \mathrm{E}-08$ & 1.57 & 174.6009744 & $=-07$ & 6.00 & 07 & 66.19298561 \\
\hline 65996 & 0 & $A Q$ & 1 & 29.4 & $4.85487 \mathrm{E}-07$ & $2.00 E-08$ & $2.64059 \mathrm{E}-07$ & 139.6779396 & $7.46877 E-07$ & $6.00 \mathrm{E}-08$ & $1.835 \mathrm{r}$ & 74.30712698 \\
\hline 60716 & 0 & $A Q$ & 1 & 62.2 & $7.7436 \mathrm{E}-07$ & 2.00 & $4.56219 \mathrm{E}-08$ & 1130 & 8.018 & & & 5202 \\
\hline 60717 & o & $A Q$ & 1 & 46 & 6.14801E-07 & $2.00 \mathrm{E}-08$ & 4.28803E-07 & 115.4 & $=-07$ & 6.0 & 2.63 & 33.94837015 \\
\hline 60647 & $\begin{array}{l}0 \\
0 \\
0\end{array}$ & $\begin{array}{c}A Q \\
A O P\end{array}$ & 1 & $\begin{array}{l}24.6 \\
70.5\end{array}$ & $\begin{array}{r}4.536 \mathrm{E}-07 \\
868481 \mathrm{E}-07\end{array}$ & $\begin{array}{l}2.00 \mathrm{E}-08 \\
2.00=08\end{array}$ & $\begin{array}{l}6.36913 \mathrm{E}-05 \\
748677 \mathrm{E}-07\end{array}$ & $\begin{array}{l}5.608212242 \\
9301198278\end{array}$ & $\begin{array}{l}7.38557 \mathrm{E}-07 \\
8.15931 E-1\end{array}$ & 6.00E-08 & 8.4165E-05 & \\
\hline $\begin{array}{l}60447 \\
59805\end{array}$ & ${ }^{0}$ & MOP & 1 & 70.5 & $\begin{array}{l}8.68481 \mathrm{E}-07 \\
2.4948 \mathrm{E}-07\end{array}$ & $\begin{array}{l}2.00 E-08 \\
200=08\end{array}$ & $\begin{array}{l}7.48677 \mathrm{E}-07 \\
2.24985 \mathrm{E}-05\end{array}$ & $\begin{array}{l}93.01198278 \\
6.887245728\end{array}$ & -07 & $\begin{array}{l}6.00 E-08 \\
600 E-08\end{array}$ & $\begin{array}{l}-06 \\
7767\end{array}$ & $\begin{array}{r}3.67176508 \\
4.369193135\end{array}$ \\
\hline $\begin{array}{l}59805 \\
59805\end{array}$ & $\begin{array}{l}A \\
B\end{array}$ & $\begin{array}{l}A Q \\
A Q\end{array}$ & 1 & $\begin{array}{l}0 \\
0\end{array}$ & $\begin{array}{l}2.14948 \mathrm{E}-07 \\
2.14948 \mathrm{E}-07\end{array}$ & $\begin{array}{l}2.00 E-08 \\
2.00 E-08\end{array}$ & $\begin{array}{r}2.24985 \mathrm{E}-05 \\
2.9588 \mathrm{E}-05\end{array}$ & $\begin{array}{l}728 \\
551\end{array}$ & $\begin{array}{l}4.02018 \mathrm{E} \\
48218 \mathrm{E}-07\end{array}$ & $\begin{array}{l}6.00 \mathrm{E}-08 \\
6.00 \mathrm{E}-08\end{array}$ & 0.000201767 & $\begin{array}{l}4.369193135 \\
1341.475004\end{array}$ \\
\hline 59805 & $\mathrm{c}$ & $A Q$ & 1 & & $2.14948 \mathrm{E}-07$ & $2.00 \mathrm{E}-08$ & $2.86583 \mathrm{E}-05$ & 6.239587502 & 482 & 600 & 0.000 & $\begin{array}{r}1 \\
-682.2442692\end{array}$ \\
\hline & $\wedge$ & $\wedge a$ & 1.0033 & 0.3 & 07 & 2.00 & 8.93 & 7.17 & 3.8992 & & 2.73 & -289.5535615 \\
\hline & $c$ & $A Q$ & 8 & 1.2 & 1.73 & 2.00 & & 7.59 & & & & 344 \\
\hline & B & $A Q$ & 5 & 0.3 & & & & & & & & \\
\hline 58878 & 0 & $A Q$ & $\begin{array}{r}1.25 \\
1323323\end{array}$ & 21.5 & 3.4731 & 2.00 & 3.75 & & & & & $\begin{array}{r}3.60273086 \\
\end{array}$ \\
\hline 578 & $\begin{array}{l}0 \\
0 \\
0\end{array}$ & AO & 1,3333333333 & 65.8 & $\begin{array}{l}6.1124 \\
27264\end{array}$ & 8 & $1.63809 \mathrm{E}-07$ & $\begin{array}{l}236.97 \\
-10.286\end{array}$ & $6.06099 \mathrm{E}-07$ & 6.00 & -4.92547 & $\begin{array}{r}3.462849183 \\
365837\end{array}$ \\
\hline 584 & $0_{0}^{0}$ & $A Q$ & $\frac{2}{2}$ & $\begin{array}{l}37.6 \\
37.6\end{array}$ & 2.72 & 8 & $\begin{array}{l}-1.65 \\
-1.32\end{array}$ & $\begin{array}{l}-10.286 \\
-97672\end{array}$ & 07 & & & $\begin{array}{r}3.6165837 \\
380.6601721\end{array}$ \\
\hline & 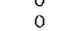 & ${ }_{A Q}$ & 2 & $\begin{array}{l}37.6 \\
47.4\end{array}$ & & & -07 & -9.1 & & & & $\begin{array}{l}380.6607 / 27 \\
184.7498047\end{array}$ \\
\hline 55 & 0 & $A Q$ & 2.5 & 82 & 3.850 & 08 & -5.27 & & & & & 303 \\
\hline & 0 & $A Q$ & $=$ & 86.1 & 3.9666 & & -7.803 & & & & & 898 \\
\hline 605 & 0 & $A Q$ & & 53.8 & 2.29081E-07 & 88 & 1.341 & & & & & 3819681 \\
\hline $\begin{array}{l}55926 \\
55926\end{array}$ & $\begin{array}{l}0 \\
0\end{array}$ & $\begin{array}{l}\mathrm{AQ} \\
\mathrm{AQ}\end{array}$ & $\begin{array}{l}3.33333333333 \\
3.3333333333\end{array}$ & $\begin{array}{l}20.2 \\
20.6\end{array}$ & $\begin{array}{r}1.2787 \mathrm{E}-07 \\
1.28955 \mathrm{E}-07\end{array}$ & $\begin{array}{l}2.00 \mathrm{E}-08 \\
2.00 \mathrm{E}-08\end{array}$ & $\begin{array}{r}1.58231 \mathrm{E}-07 \\
-2.11678 \mathrm{E}-07\end{array}$ & $\begin{array}{r}73.13011522 \\
-26.22822211\end{array}$ & $\begin{array}{l}2.19228 \mathrm{E}-07 \\
2.19443 \mathrm{E}-7\end{array}$ & $\begin{array}{l}6.00 \mathrm{E}-08 \\
6.00 \mathrm{E}-08\end{array}$ & $\begin{array}{l}8.40827 \mathrm{E}-07 \\
1.70701 \mathrm{~F}-06\end{array}$ & $\begin{array}{l}45.26108556 \\
7.851791131\end{array}$ \\
\hline AQ-DM Average: & & & $\begin{array}{r}1.1287 \\
86356202\end{array}$ & 40.93947368 & $1.03927 \mathrm{E}-06$ & & & & 6 & & & \\
\hline AQ-DM & & & & & 1039.266159 & & & & 1411.04908 & & & \\
\hline
\end{tabular}

Total 38 Samples

Sample Size (ml)

$$
\begin{array}{r}
<1 \\
1 \text { to } 5 \\
5 \text { to } 10 \\
10 \text { to } 20
\end{array}
$$

13
25
0
0

Notes:

Data Provided by Reggi $\theta$ Gaylord 9/2
Samples sizes for $A Q-D M$ are $<5 \mathrm{ml}$. 


\section{Appendix C - Oil}

Oil (OI)

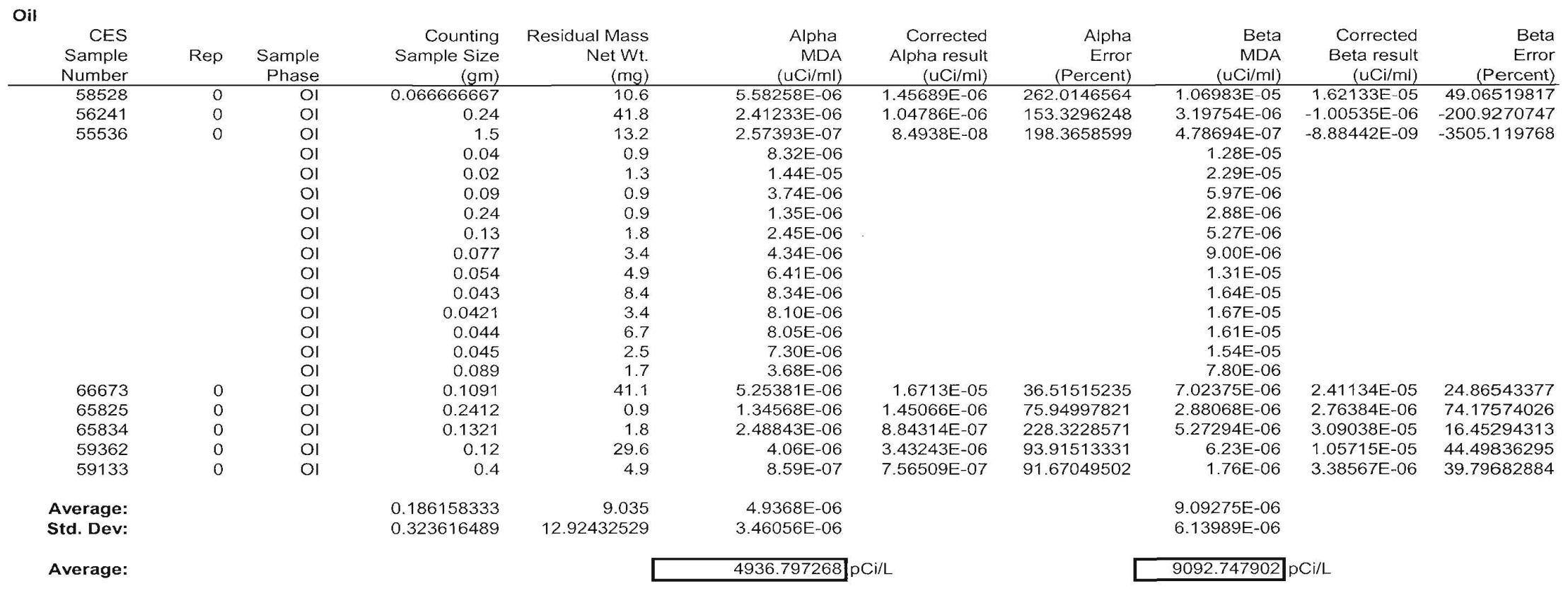

\section{Total 21 Samples}

Notes:

Data Provided by Reggie Gaylord 9/21/06

Oil specific gravity assumed to be $0.85 \mathrm{~g} / \mathrm{ml}$ 


\section{Appendix D - Solids/Sludges}

Solids, Sludges (SO, SL)

Solids, Sludges

$$
\text { CES }
$$

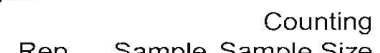

0.253
Net Wt.

$\begin{array}{rr}\text { Alpha } & \text { Corrected } \\ \text { MDA Alpha result }\end{array}$

Number Phase

$\begin{array}{rr}X X & 0.253 \\ X X & 0.08866667 \\ X X & 0.1508\end{array}$

$\begin{array}{rrrr}58638 & 0 & X X & 0.08866667 \\ 58639 & 0 & X X & 0.1508 \\ 58641 & 0 & X X & 0.148\end{array}$

58641

58695

58701

0.148

$x \times 0.09866667$

$x x$

0.508

$\begin{array}{lr}X X & 0.08666667 \\ X X & 0.09833333\end{array}$

58748

58793

58794

58473

58474

58502

58503

58504

58505

58101

58102

58104

58105

58106

58107

58108

58109
58110
58111

58111

58113

58114

58115

58116

58117

0.256

0.10985

0.11505

0.231

0.25

0.283

0.283

0.254

0.106

0.112

0.1332

0.115
0.09

0.09
0.106

0.11

0.0888

0.1155

0.0964

0.11
0.111

0.112

0.115

0.115

0.092

0.118

0.092

(mg)

$\begin{array}{rr}(\mathrm{UCl} / \mathrm{g}) & (\mathrm{uCi} / \mathrm{g})\end{array}$

$4.37000 \mathrm{E}-06$.000982748

2.87078E-06 2.99794E-06

2.21172E-06 2.77215E-06

4.48806E-06 6.86955E-06

$\begin{array}{rr}6.64659 \mathrm{E}-07 & 4.76988 \mathrm{E}-08 \\ 4.86964 \mathrm{E}-06 & 1.0162 \mathrm{E}-05\end{array}$

3.52695E-06 $1.81449 E-06$

$\begin{array}{rrr}5.6 & 3.52695 \mathrm{E}-06 & 1.81449 \mathrm{E}-06 \\ 10.3 & 4.44879 \mathrm{E}-06 & 0.005785413\end{array}$

\begin{tabular}{l}
$98.7 \quad 9.6641 \mathrm{E}-06 \quad 6.98927 \mathrm{E}-06$ \\
\hline
\end{tabular}

$\begin{array}{lll}94.7 & 9.06397 \mathrm{E}-06 & 2.09562 \mathrm{E}-05 \\ 5.29 & 2.02852 \mathrm{E}-06 & 7.76598 \mathrm{E}-06\end{array}$

$\begin{array}{lll}10.6 & 2.02018 \mathrm{E}-06 & 0.001441071\end{array}$

$\begin{array}{lll}33.5 & 2.79263 \mathrm{E}-06 & 1.9672 \mathrm{E}-06\end{array}$

$\begin{array}{lll}17.2 & 1.95895 \mathrm{E}-06 & 2.30646 \mathrm{E}-05 \\ 15 & 2.11582 \mathrm{E}-06 & 3.25687 \mathrm{E}-05\end{array}$

$24.5 \quad 2.42946 \mathrm{E}-06 \quad 1.27251 \mathrm{E}-06$

$\begin{array}{lll}37.8 & 5.15888 \mathrm{E}-06 & 2.13112 \mathrm{E}-06\end{array}$

$46.3 \quad 5.51289 \mathrm{E}-06 \quad 3.07335 \mathrm{E}-06$

$55 \quad 5.24821 \mathrm{E}-06 \quad 3.34549 \mathrm{E}-06$

49.3 5.60431E-06 1.59741E-06

$46.2 \quad 6.85068 \mathrm{E}-06 \quad 2.43503 \mathrm{E}-06$

$44.5 \quad 5.67694 \mathrm{E}-06 \quad 1.20833 \mathrm{E}-07$

$46.8 \quad 5.65339 \mathrm{E}-06 \quad 1.44575 \mathrm{E}-06$

$35.4 \quad 5.95216 \mathrm{E}-06 \quad 6.56476 \mathrm{E}-07$

$63.8 \quad 6.85855 \mathrm{E}-06 \quad 3.05844 \mathrm{E}-06$

$50.8 \quad 6.83048 \mathrm{E}-06 \quad 1.98611 \mathrm{E}-06$

$51.5 \quad 6.04615 \mathrm{E}-06 \quad 5.95376 \mathrm{E}-06$

$37.7 \quad 4.91952 \mathrm{E}-06 \quad 3.8304 \mathrm{E}-06$

$52.1 \quad 5.98929 \mathrm{E}-06 \quad 3.06147 \mathrm{E}-06$

$\begin{array}{llr}55.5 & 6.12214 \mathrm{E}-06 & 2.3212 \mathrm{E}-06\end{array}$

$37.5 \quad 5.9187 \mathrm{E}-06 \quad 3.14663 \mathrm{E}-06$

$\begin{array}{lll}53.1 & 5.76644 \mathrm{E}-06 & 7.22747 \mathrm{E}-06 \\ 50.7 & 5.71755 \mathrm{E}-06 & 1.70828 \mathrm{E}-06\end{array}$

$\begin{array}{lll}50.7 & 5.71755 \mathrm{E}-06 & 1.70828 \mathrm{E}-06 \\ 32.3 & 5.49826 \mathrm{E}-06 & 3.59173 \mathrm{E}-06\end{array}$

1 of 4

Appendix D

\begin{tabular}{|c|c|c|c|}
\hline Alpha & Beta & Corrected & $\begin{array}{l}\text { Beta } \\
\text { Error }\end{array}$ \\
\hline $\begin{array}{r}\text { Error } \\
\text { (Percent) }\end{array}$ & $\begin{array}{r}\text { MDA } \\
\text { (uCi/g) }\end{array}$ & $\begin{array}{r}\text { Beta result } \\
(\mathrm{uCi} / \mathrm{g})\end{array}$ & $\begin{array}{r}\text { Error } \\
\text { (Percent) }\end{array}$ \\
\hline 5.275802496 & $2.99925 \mathrm{E}-06$ & 0.001786695 & 3.078308139 \\
\hline 141.2335165 & $8.10651 \mathrm{E}-06$ & 2.36656E-05 & 28.10844607 \\
\hline 81.55506866 & 4.85892E-06 & $1.334 \mathrm{E}-05$ & 29.59895944 \\
\hline 69.74969379 & 4.70255E-06 & $1.02291 \mathrm{E}-05$ & 35.91746536 \\
\hline 61.71153289 & 7.45504E-06 & $2.73139 \mathrm{E}-05$ & 23.501346 \\
\hline 915.7625575 & $1.37834 \mathrm{E}-06$ & $2.64172 \mathrm{E}-06$ & 39.96980114 \\
\hline 48.42152368 & 8.41738E-06 & $2.54752 \mathrm{E}-05$ & 27.35534095 \\
\hline 143.0417946 & $7.15746 \mathrm{E}-06$ & 1.1726E-05 & 45.82201425 \\
\hline 3.462628826 & $7.35942 \mathrm{E}-06$ & 0.001146983 & 4.097919438 \\
\hline 102.0921306 & $7.78188 \mathrm{E}-06$ & 4.39173E-06 & 122.3621524 \\
\hline 45.31573545 & $7.39026 \mathrm{E}-06$ & $2.5623 E-05$ & 25.68193316 \\
\hline 34.5399888 & 3.99279E-06 & $1.89429 \mathrm{E}-05$ & 19.21964763 \\
\hline 3.619006768 & $3.74175 \mathrm{E}-06$ & 0.002484153 & 1.999440639 \\
\hline 114.6475831 & $3.95469 \mathrm{E}-06$ & 1.55489E-05 & 21.97539991 \\
\hline 17.92080767 & 3.36165E-06 & 1.41706E-05 & 21.04207625 \\
\hline 15.94669095 & 3.72477E-06 & $4.06838 \mathrm{E}-05$ & 11.35587171 \\
\hline 132.6792552 & 3.82777E-06 & $5.45002 \mathrm{E}-06$ & 47.99180148 \\
\hline 161.3992837 & 7.17873Е-06 & -1.0476 E-06 & -440.4430019 \\
\hline 126.6273991 & $6.91515 \mathrm{E}-06$ & 2.02949E-06 & 228.7291679 \\
\hline 112.6057815 & 5.92016E-06 & 1.10841E-06 & 355.0884195 \\
\hline 223.4059561 & $6.77487 \mathrm{E}-06$ & $-1.40561 E-06$ & -307.8942962 \\
\hline 187.3112291 & $8.6038 \mathrm{E}-06$ & 2.54792E-06 & 226.6764909 \\
\hline 2789.058726 & 7.28006E-06 & 2.03474E-06 & 239.6840472 \\
\hline 249.2397182 & 33E-06 & 1.703 & 2704.545047 \\
\hline 552.9512411 & $8.52468 \mathrm{E}-06$ & 9.39177E-07 & 598.1833624 \\
\hline 151.9046756 & 6.96671E-06 & 7.35732E-07 & 624.5482049 \\
\hline 223.9295501 & $8.10561 \mathrm{E}-06$ & 2.23687E-06 & 242.7939505 \\
\hline 79.22598207 & 7.11303E-06 & $7.01081 \mathrm{E}-07$ & 668.9548751 \\
\hline 97.32193034 & $6.85389 \mathrm{E}-06$ & 4.5851E-06 & 103.8469 \\
\hline 135.3433495 & 6.99403E-06 & $8.8032 E-07$ & 524.9034441 \\
\hline 175.2221253 & 6.86533E-06 & $7.31665 \mathrm{E}-07$ & 618.732603 \\
\hline 130.5104553 & $8.2658 \mathrm{E}-06$ & $-1.76568 E-07$ & -3047.35357 \\
\hline 65.97744458 & 6.65194E-06 & 6.31585E-07 & 694.4814964 \\
\hline 217.9178673 & $6.79331 \mathrm{E}-06$ & 1.44554E-06 & 312.99458 \\
\hline 110.2568003 & $8.1718 \mathrm{E}-06$ & 6.71896E-07 & 799.8462037 \\
\hline
\end{tabular}

$8.1718 \mathrm{E}-06 \quad 6.71896 \mathrm{E}-07 \quad 799.8462037$ 
Solids, Sludges (SO, SL)

Solids, Sludges

\begin{tabular}{|c|c|c|c|c|c|c|c|c|c|c|}
\hline $\begin{array}{l}\text { CES } \\
\text { Sample } \\
\text { Number }\end{array}$ & Rep & $\begin{array}{r}\text { Sample } \\
\text { Phase } \\
\end{array}$ & $\begin{array}{r}\text { Counting } \\
\text { Sample Size } \\
(\mathrm{g}) \\
\end{array}$ & $\begin{array}{r}\text { Residual Mass } \\
\text { Net Wt. } \\
(\mathrm{mg})\end{array}$ & $\begin{array}{r}\text { Alpha } \\
\text { MDA } \\
\text { (uCi/g) }\end{array}$ & $\begin{array}{r}\text { Corrected } \\
\text { Alpha result } \\
(\mathrm{uCi} / \mathrm{g})\end{array}$ & $\begin{array}{r}\text { Alpha } \\
\text { Error } \\
\text { (Percent) }\end{array}$ & $\begin{array}{r}\text { Beta } \\
\mathrm{MDA} \\
(\mathrm{uCi} / \mathrm{g})\end{array}$ & $\begin{array}{r}\text { Corrected } \\
\text { Beta result } \\
(\mathrm{uCi} / \mathrm{g})\end{array}$ & $\begin{array}{r}\text { Beta } \\
\text { Error } \\
\text { (Percent) }\end{array}$ \\
\hline 58119 & 0 & $x x$ & 0.0928 & 44.6 & $6.49371 \mathrm{E}-06$ & 3.32652E-07 & 1126.825695 & $8.31728 \mathrm{E}-06$ & $-3.97242 \mathrm{E}-06$ & -129.9263432 \\
\hline 58120 & 0 & $x x$ & 0.12 & 47.4 & $5.22691 \mathrm{E}-06$ & $1.9647 \mathrm{E}-07$ & 1577.660794 & 6.46832E-06 & $9.90763 \mathrm{E}-07$ & 432.1483854 \\
\hline 58121 & 0 & $x x$ & 0.0896 & 29 & $5.38778 \mathrm{E}-06$ & 2.8821E-06 & 129.8089268 & $8.32802 E-06$ & $-3.52286 E-07$ & -1535.28618 \\
\hline 58122 & 0 & $x x$ & 0.115 & 40.2 & 4.9205E-06 & $9.82014 \mathrm{E}-07$ & 312.6440338 & $6.65081 \mathrm{E}-06$ & $-3.93235 E-07$ & -1096.405541 \\
\hline 58123 & 0 & $x x$ & 0.116 & 43 & $5.07744 \mathrm{E}-06$ & $2.03911 \mathrm{E}-06$ & 165.843479 & 6.63207E-06 & $-4.09735 \mathrm{E}-07$ & -1049.377399 \\
\hline 58124 & 0 & $x x$ & 0.0888 & 38.1 & $6.18436 \mathrm{E}-06$ & $1.58448 \mathrm{E}-06$ & 249.3355283 & 8.57473E-06 & 2.07692E-07 & 2698.726455 \\
\hline 58125 & 0 & $x \times$ & 0.119 & 46.7 & $5.21835 E-06$ & 3.50862E-07 & 905.1340559 & 6.51359E-06 & 2.91205E-06 & 152.2206342 \\
\hline 58126 & 0 & $x x$ & 0.113 & 40.9 & 5.05799E-06 & $3.24534 \mathrm{E}-06$ & 112.153759 & $6.77849 \mathrm{E}-06$ & 1.12741E-06 & 398.7299145 \\
\hline 58127 & 0 & $x x$ & 0.1008 & 48.3 & $6.30308 \mathrm{E}-06$ & 5.92064E-07 & 630.6468663 & 7.71411E-06 & $-2.2296 \mathrm{E}-06$ & -219.089378 \\
\hline 58128 & 0 & $x x$ & 0.1024 & 48.2 & $6.19573 \mathrm{E}-06$ & 2.38487E-06 & 172.8354385 & $7.59208 \mathrm{E}-06$ & 4.89737E-07 & 1017.821748 \\
\hline 58129 & 0 & $x x$ & 0.0968 & 38.5 & $5.70552 \mathrm{E}-06$ & 2.88225E-06 & 134.6392798 & 7.87281E-06 & $-2.64747 \mathrm{E}-06$ & -187.4295762 \\
\hline 58130 & 0 & $x x$ & 0.204 & 16.8 & $1.99134 \mathrm{E}-06$ & 3.91833E-07 & 310.1902372 & 3.55211E-06 & $-1.92551 E-06$ & -113.5829074 \\
\hline 58131 & 0 & $x x$ & 0.095 & 15.2 & $4.18055 \mathrm{E}-06$ & 1.61282E-06 & 169.5301027 & $7.59698 \mathrm{E}-06$ & $-3.33784 E-06$ & -141.7519863 \\
\hline 58163 & 0 & $x x$ & 0.1 & 38 & $5.48394 \mathrm{E}-06$ & 3.045E-06 & 127.3643365 & $7.61272 \mathrm{E}-06$ & $2.39486 \mathrm{E}-06$ & 213.7589494 \\
\hline 58164 & 0 & $x x$ & 0.1 & 36.4 & $5.36096 E-06$ & 8.56055E-07 & 381.6042863 & 7.58645E-06 & $-2.0388 E-06$ & -236.0690351 \\
\hline 58165 & 0 & $x x$ & 0.1 & 37.8 & $5.46841 \mathrm{E}-06$ & 1.91084E-05 & 32.98348843 & 7.60945E-06 & $3.86422 \mathrm{E}-06$ & 135.2855753 \\
\hline 58166 & 0 & $x x$ & 0.1 & 34.3 & $5.20377 \mathrm{E}-06$ & $3.83585 \mathrm{E}-06$ & 99.3991715 & $7.55161 \mathrm{E}-06$ & $-3.39581 E-07$ & -1444.458165 \\
\hline 58167 & 0 & $x x$ & 0.1 & 46.3 & $6.17443 \mathrm{E}-06$ & 7.97394E-07 & 470.8897755 & 7.74497E-06 & $-2.8828 E-07$ & -1745.565293 \\
\hline 58168 & 0 & $x x$ & 0.096 & 43.3 & $6.16163 \mathrm{E}-06$ & 2.20935E-06 & 181.8126416 & 8.0187E-06 & $-2.00784 \mathrm{E}-06$ & -253.9723839 \\
\hline 56010 & 0 & $x x$ & 0.4 & 47.6 & 1.57256E-06 & 1.90544E-05 & 18.13150161 & 1.94127E-06 & 3.53693E-05 & 8.314617529 \\
\hline 56011 & 0 & $x x$ & 0.09666667 & 48.1 & $6.55382 \mathrm{E}-06$ & 0.002155424 & 7.158656612 & 8.04078E-06 & 0.005857626 & 3.285247906 \\
\hline 56012 & 0 & $x x$ & 0.52 & 47.6 & $1.20966 \mathrm{E}-06$ & 2.55133E-05 & 14.06921014 & 1.49328E-06 & 4.41074E-05 & 6.58146584 \\
\hline 56013 & 0 & $x x$ & 0.16 & 75.2 & $5.68116 \mathrm{E}-06$ & 0.000243109 & 12.1408492 & 5.1465E-06 & 0.00059183 & 7.630399604 \\
\hline 56014 & 0 & $x x$ & 0.2 & 50.9 & $3.297 \mathrm{E}-06$ & 0.000228432 & 9.597098136 & 3.90766E-06 & 0.000377539 & 4.360232102 \\
\hline 56024 & 0 & $x x$ & 0.08266667 & 75.6 & 1.10361E-05 & 0.000771535 & 9.933957494 & 9.96847E-06 & 0.000893598 & 7.806418122 \\
\hline 56127 & 0 & $x x$ & 0.13 & 80.6 & 7.32419E-06 & 0.000692358 & 10.414057 & $6.39675 \mathrm{E}-06$ & 0.001812915 & 7.587949912 \\
\hline 66654 & 0 & $x x$ & 0.031975 & 34.7 & 1.6367E-05 & 0.000990309 & 8.040520134 & $2.36381 \mathrm{E}-05$ & 0.000159134 & 15.57924891 \\
\hline 66656 & 0 & $x x$ & 0.03355 & 37.8 & 1.62993E-05 & 0.002729646 & 6.419863346 & 2.26809E-05 & 0.004190565 & 3.611389284 \\
\hline 66719 & 0 & $x x$ & 0.036075 & 64.5 & $2.21782 \mathrm{E}-05$ & $3.02294 \mathrm{E}-05$ & 66.39966972 & $2.2339 \mathrm{E}-05$ & $6.64435 \mathrm{E}-05$ & 28.39864331 \\
\hline 66721 & 0 & $x x$ & 0.053225 & 58.6 & 1.38234E-05 & $6.57273 \mathrm{E}-05$ & 29.48377918 & $1.49422 \mathrm{E}-05$ & $8.77448 \mathrm{E}-05$ & 17.37737851 \\
\hline 66759 & 0 & $x x$ & 0.026825 & 10.8 & 1.39133E-05 & $5.37587 \mathrm{E}-05$ & 32.56046398 & $2.66018 \mathrm{E}-05$ & 0.000130209 & 18.79957743 \\
\hline 66761 & 0 & $x x$ & 0.02785 & 17.7 & $1.47732 \mathrm{E}-05$ & 0.000285803 & 13.22890224 & 2.60776E-05 & 0.000481979 & 7.874875638 \\
\hline 66118 & 0 & $x x$ & 0.036275 & 98.3 & $2.92178 \mathrm{E}-05$ & $3.61444 \mathrm{E}-05$ & 70.9133489 & 2.35533E-05 & 7.01336E-05 & 28.71902089 \\
\hline 66129 & 0 & $x x$ & 0.0315 & 40.6 & $1.80668 \mathrm{E}-05$ & 1.93702E-05 & 76.15249049 & $2.43012 E-05$ & $2.43362 \mathrm{E}-05$ & 71.42289328 \\
\hline 66144 & 0 & $x x$ & 0.031275 & 24.8 & 1.45447E-05 & $6.23543 E-05$ & 30.37040245 & 2.36261E-05 & 0.000112548 & 19.26994136 \\
\hline
\end{tabular}


Solids, Sludges (SO, SL)

Solids, Sludges

CES

CES
Sample Rep Sample Sample Size

Number

$\begin{array}{rrr}66146 & 0 & \text { Phase } \\ 66148 & 0 & X X\end{array}$

66148

66380

\begin{tabular}{c} 
Phase \\
\hline$X X$ \\
$X X$
\end{tabular}

ample Size

0.040225

0.039475

0.023175

0.048225

$\begin{array}{llll}66387 & 0 & X X & 0.029075\end{array}$

$\begin{array}{rrrr}60705 & 0 & X X & 0.0625\end{array}$

$\begin{array}{llll}60706 & 0 & X X & 0.125\end{array}$

$\begin{array}{rrrr}60707 & 0 & X X & 0.125 \\ 60361 & 0 & X X & 0.5\end{array}$

$\begin{array}{llll}60362 & 0 & X X & 0.5 \\ 60363 & 0 & X X & 0.35\end{array}$

$\begin{array}{llll}60363 & 0 & X X & 0.25\end{array}$

$\begin{array}{rrrr}60364 & 0 & X X & 0.25\end{array}$

$\begin{array}{llll}60484 & 0 & X X & 0.2472\end{array}$

$\begin{array}{llll}60485 & 0 & X X & 0.2472\end{array}$

$\begin{array}{llll}59603 & A & X X & 0.23733333\end{array}$

$\begin{array}{llll}59603 & B & X X & 0.23666667\end{array}$

$\begin{array}{llll}59797 & 0 & X X & 0.125\end{array}$

$\begin{array}{llll}59798 & 0 & X X & 0.15\end{array}$

$\begin{array}{llll}59659 & 0 & X X & 0.706\end{array}$

$\begin{array}{llll}59660 & 0 & X X & 0.7\end{array}$

$\begin{array}{llll}59661 & 0 & X X & 0.568\end{array}$

$\begin{array}{llll}59662 & 0 & X X & 0.4224\end{array}$

$\begin{array}{llll}59663 & 0 & X X & 0.531\end{array}$

$\begin{array}{llll}59664 & 0 & X X & 0.528\end{array}$

$\begin{array}{llll}59665 & 0 & X X & 0.534\end{array}$

$\begin{array}{llll}59666 & 0 & X X & 0.534\end{array}$

$\begin{array}{llll}59667 & 0 & X X & 0.5325\end{array}$

$\begin{array}{llll}59668 & 0 & X X & 0.5295\end{array}$

$\begin{array}{llll}59669 & 0 & X X & 0.4248\end{array}$

$\begin{array}{llll}59670 & 0 & X X & 0.4224\end{array}$

$\begin{array}{llll}59671 & 0 & X X & 0.4296\end{array}$

$\begin{array}{llll}59672 & 0 & X X & 0.537\end{array}$

$\begin{array}{llll}59673 & 0 & X X & 0.4272\end{array}$

$\begin{array}{llll}59674 & 0 & X X & 0.4284\end{array}$

59675

$X X$

0.528
Residual Mass $\quad$ Alpha Corrected MDA Alpha result Net Wt. $(\mathrm{uCi} / \mathrm{g}) \quad(\mathrm{uCi} / \mathrm{g})$

$\begin{array}{lrr}(\mathrm{mg}) & \\ 33.5 & 1.27909 \mathrm{E}-05 & 4.3395 \mathrm{E}-06\end{array}$

$\begin{array}{rrr}45.8 & 1.553 \mathrm{E}-05 & 2.79851 \mathrm{E}-06 \\ 25.7 & 1.98799 \mathrm{E}-05 & 2.80836 \mathrm{E}-05\end{array}$

93.7 2.15157E-05 8.40291E-05

3.9 1.16458E-05 1.31492E-05

$53.7 \quad 1.09803 \mathrm{E}-05 \quad 1.42378 \mathrm{E}-05$

$\begin{array}{lll}57.3 & 5.77829 \mathrm{E}-06 & 6.12804 \mathrm{E}-06\end{array}$

$52.5 \quad 5.39716 \mathrm{E}-06 \quad 3.28281 \mathrm{E}-06$

$\begin{array}{lll}11 & 7.4856 \mathrm{E}-07 & 2.21225 \mathrm{E}-07\end{array}$

$4.3 \quad 1.13505 \mathrm{E}-06 \quad 1.34248 \mathrm{E}-06$

$25.3 \quad 1.83246 \mathrm{E}-06 \quad 1.34141 \mathrm{E}-06$

$10.3 \quad 1.4824 \mathrm{E}-06 \quad 2.83713 \mathrm{E}-07$

$12.5 \quad 1.54649 \mathrm{E}-06 \quad 5.90202 \mathrm{E}-06$

$\begin{array}{lll}12.9 & 1.55525 \mathrm{E}-06 & 8.99405 \mathrm{E}-06\end{array}$

1.84222E-06 3.04146E-06

2.03977E-06 2.64246E-06

$\begin{array}{lll}5.1 & 2.75504 \mathrm{E}-06 \quad 9.64573 \mathrm{E}-07\end{array}$

$13 \quad 2.56667 \mathrm{E}-06 \quad 6.38872 \mathrm{E}-07$

62.9 1.10779E-06 2.53296E-06

$62 \quad 1.10309 \mathrm{E}-06 \quad 2.35174 \mathrm{E}-06$

$\begin{array}{lll}47.7 & 1.10902 E-06 & 3.22973 E-06\end{array}$

$34.8 \quad 1.24071 \mathrm{E}-06 \quad 2.53633 \mathrm{E}-06$

$\begin{array}{lll}54.7 & 1.3109 \mathrm{E}-06 \quad 2.78935 \mathrm{E}-06\end{array}$

72.5 1.67806E-06 4.66019E-06

$68.21 .57913 \mathrm{E}-06 \quad 3.25159 \mathrm{E}-06$

$\begin{array}{lll}59.1 & 1.38763 \mathrm{E}-06 & 2.96068 \mathrm{E}-06\end{array}$

$56.4 \quad 1.33917 \mathrm{E}-06 \quad 3.39606 \mathrm{E}-06$

$56.2 \quad 1.34294 \mathrm{E}-06 \quad 3.01403 \mathrm{E}-06$

$37.2 \quad 1.27639 \mathrm{E}-06 \quad 2.77366 \mathrm{E}-06$

$32.3 \quad 1.19754 \mathrm{E}-06 \quad 1.96574 \mathrm{E}-06$

$37.8 \quad 1.27291 \mathrm{E}-06 \quad 3.05535 \mathrm{E}-06$

$49.1 \quad 1.19675 \mathrm{E}-06 \quad 2.98338 \mathrm{E}-06$

40.2 1.32457E-06 3.87063E-06

$49.8 \quad 1.51521 \mathrm{E}-06 \quad 4.04166 \mathrm{E}-06$

$42.8 \quad 1.11231 E-06 \quad 3.63667 \mathrm{E}-06$

$$
3 \text { of } 4
$$

Appendix D

\begin{tabular}{|c|c|c|c|}
\hline $\begin{array}{r}\text { Alpha } \\
\text { Error } \\
\text { (Percent) }\end{array}$ & $\begin{array}{r}\text { Beta } \\
\mathrm{MDA} \\
(\mathrm{uCi} / \mathrm{g}) \\
\end{array}$ & $\begin{array}{r}\text { Corrected } \\
\text { Beta result } \\
(\mathrm{uCi} / \mathrm{g})\end{array}$ & $\begin{array}{r}\text { Beta } \\
\text { Error } \\
\text { (Percent) }\end{array}$ \\
\hline 204.9942331 & $1.87402 \mathrm{E}-05$ & $2.72132 \mathrm{E}-05$ & 51.036726 \\
\hline 543 & $96002 E-05$ & 6299E-05 & $508-8$ \\
\hline 213 & 9517E-05 & 01 & \\
\hline 33.21391418 & $.76061 E-05$ & .000111406 & 7320757 \\
\hline 11 & 56E- & & 4 \\
\hline 67 & 7773E-05 & 55 & \\
\hline 332 & $3 E-06$ & & \\
\hline 16 & 27142E-06 & 25 & 92 \\
\hline 240.5316696 & 42793E-06 & & 80021 \\
\hline 72.0 & 1 & & $2<5$ \\
\hline 1 & 135-06 & ( & 000 \\
\hline 304. & 065E-06 & $r .20$ & \\
\hline 32.9 & 46E-06 & & \\
\hline 25. & 245E-06 & & \\
\hline 5 & $E$ & & 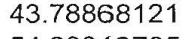 \\
\hline 1.4 & $2 E-06$ & 4.2 & 340 \\
\hline 19 & E-06 & & \\
\hline & & & \\
\hline 46. & ( & & 10 \\
\hline 49.0 & 5E-06 & 66 & 2 \\
\hline & $36 E-06$ & & \\
\hline & & & \\
\hline & & & 547 \\
\hline & & & \\
\hline & 3E & & 9 \\
\hline 48. & & & 61 \\
\hline 43.32 & & & 525063 \\
\hline & & & \\
\hline & & & \\
\hline 58.1257 & $7984 E-$ & $=-06$ & 25.292603 \\
\hline 44.4 & $29 \mathrm{E}-$ & -06 & 3.24136449 \\
\hline 43.574625 & 45029E-06 & $5.93742 \mathrm{E}-06$ & 21.70706022 \\
\hline & & & . \\
\hline & & & \\
\hline & $45644 F_{-}$ & $628423 F$ & \\
\hline
\end{tabular}

Adjusted MDA 011007.xls SO, SL. 
Solids, Sludges (SO, SL)

\section{Solids, Sludges}

\begin{tabular}{|c|c|c|c|c|c|c|c|c|c|c|}
\hline $\begin{array}{l}\text { CES } \\
\text { Sample } \\
\text { Number }\end{array}$ & Rep & $\begin{array}{c}\text { Sample } \\
\text { Phase }\end{array}$ & $\begin{array}{r}\text { Counting } \\
\text { Sample Size } \\
(\mathrm{g})\end{array}$ & $\begin{array}{r}\text { Residual Mass } \\
\text { Net Wt } \\
(\mathrm{mg})\end{array}$ & $\begin{array}{r}\text { Alpha } \\
\text { MDA } \\
(\mathrm{uCi} / \mathrm{g})\end{array}$ & $\begin{array}{r}\text { Corrected } \\
\text { Alpha result } \\
(\mathrm{uCi} / \mathrm{g})\end{array}$ & $\begin{array}{r}\text { Alpha } \\
\text { Error } \\
\text { (Percent) }\end{array}$ & $\begin{array}{r}\text { Beta } \\
\mathrm{MDA} \\
(\mathrm{uCi} / \mathrm{g})\end{array}$ & $\begin{array}{r}\text { Corrected } \\
\text { Beta result } \\
(\mathrm{uCi} / \mathrm{g})\end{array}$ & $\begin{array}{r}\text { Beta } \\
\text { Error } \\
\text { (Percent) }\end{array}$ \\
\hline 59676 & 0 & $x x$ & 0.5325 & 42.3 & $1.09505 \mathrm{E}-06$ & $2.15367 \mathrm{E}-06$ & 51.93249797 & $1.44264 \mathrm{E}-06$ & $6.49173 \mathrm{E}-06$ & 20.18772831 \\
\hline 59677 & 0 & $x x$ & 0.426 & 33.8 & $1.21292 \mathrm{E}-06$ & $3.19811 \mathrm{E}-06$ & 41.7292284 & 1.77072E-06 & $7.05882 E-06$ & 22.09569218 \\
\hline 59678 & 0 & $x x$ & 0.472 & 40.3 & $1.20057 \mathrm{E}-06$ & $3.01259 E-06$ & 42.86252104 & 1.62077E-06 & $5.54437 \mathrm{E}-06$ & 24.91944748 \\
\hline 59679 & 0 & $x x$ & 0.4284 & 34.7 & $1.2216 \mathrm{E}-06$ & $3.71262 E-06$ & 37.87042864 & 1.7643E-06 & 7.06127E-06 & 22.04001195 \\
\hline 59680 & 0 & $x x$ & 0.4224 & 45.2 & $1.43894 \mathrm{E}-06$ & $3.98825 \mathrm{E}-06$ & 40.42178019 & $1.82951 \mathrm{E}-06$ & 7.32911E-06 & 22.06534287 \\
\hline 59681 & 0 & $x x$ & 0.4248 & 39.2 & $1.31313 \mathrm{E}-06$ & $2.72363 \mathrm{E}-06$ & 49.23391636 & $1.79667 \mathrm{E}-06$ & $6.57153 \mathrm{E}-06$ & 23.63500986 \\
\hline 59682 & 0 & $x x$ & 0.528 & 42.4 & $1.10597 \mathrm{E}-06$ & 3.26706E-06 & 38.76323884 & $1.45524 \mathrm{E}-06$ & $6.0403 \mathrm{E}-06$ & 21.47063527 \\
\hline 58218 & 0 & $\mathrm{SL}$ & 0.25 & 69.7 & $3.44568 \mathrm{E}-06$ & 2.16216 E-05 & 25.91939942 & $3.25845 \mathrm{E}-06$ & $2.32486 \mathrm{E}-05$ & 15.77592453 \\
\hline 58210 & 0 & SL & 0.25 & 66.7 & 3.3019E 06 & $9.67326 \mathrm{E}-06$ & 39.07151551 & 3.2387E-06 & $1.07218 \mathrm{E}-05$ & 26.24459489 \\
\hline 58220 & 0 & $\mathrm{SL}$ & 0.25 & 58.2 & $2.92633 \mathrm{E}-06$ & $8.86144 \mathrm{E}-05$ & 12.85139861 & 3.17825E-06 & $8.4068 \mathrm{E}-05$ & 8.446478756 \\
\hline 55966 & 0 & $S L$ & 0.04 & 56.6 & $1.78784 E-05$ & $4.82826 E-05$ & 41.68598114 & 1.97896E-05 & 9.09554E-05 & 20.4342611 \\
\hline 55967 & 0 & SL & 0.0625 & 52.3 & $1.07635 \mathrm{E}-05$ & $1.50629 \mathrm{E}-05$ & 71.66324732 & $1.25381 \mathrm{E}-05$ & 0.000100017 & 13.51338996 \\
\hline 55968 & 0 & SL & 0.0825 & 66.7 & $1.00058 \mathrm{E}-05$ & $2.22315 E-05$ & 52.01455824 & $9.81425 E-06$ & 9.92569E-05 & 12.94348421 \\
\hline 55996 & 0 & SL & 0.0625 & 77.2 & $1.48068 E-05$ & $2.41045 E-05$ & 63.93671947 & $1.32242 \mathrm{E}-05$ & 0.000112472 & 14.51239963 \\
\hline 59259 & 0 & $Z Z$ & 0.05 & 23.2 & $8.8941 \mathrm{E}-06$ & 0.000117734 & 15.60361631 & $1.47219 \mathrm{E}-05$ & $7.28058 \mathrm{E}-05$ & 18.83592743 \\
\hline 59260 & 0 & $z Z$ & 0.05 & 15.6 & 7.98807E-06 & 0.000111957 & 15.12358558 & 1.44489E-05 & 8.28706 E-05 & 16.84089463 \\
\hline Average: & & & 0.21049167 & 41.04454545 & $5.75495 \mathrm{E}-06$ & & & 7.48793E-06 & & \\
\hline Std. Dev: & & & 0.17464808 & & & & & & & \\
\hline Average: & & & & & 5.754950838 & $\mathrm{Ci} / \mathrm{g}$ & & 7.48793201 & & \\
\hline
\end{tabular}

Total 121 Samples

CES Matrix Codes

$X X$ - Other Solid (debris, lab trash, etc.)

$S L$ - Sludge

ZZ - Other "liquid" (Viscous, multiphase, very high solids, etc.)

Notes:

- Data Provided by Reggie Gaylord 9/21/06. 


\section{Appendix E - Solvents}

Solvents (SV)

\begin{tabular}{|c|c|c|c|c|c|c|c|c|c|c|}
\hline $\begin{array}{r}\text { Solvent } \\
\text { CES } \\
\text { Sample } \\
\text { Number } \\
\end{array}$ & Rep & $\begin{array}{r}\text { Sample } \\
\text { Phase } \\
\end{array}$ & $\begin{array}{r}\text { Counting } \\
\text { Sample Size } \\
(\mathrm{ml}) \\
\end{array}$ & $\begin{array}{r}\text { Residual Mass } \\
\text { Net Wt. } \\
(\mathrm{mg})\end{array}$ & $\begin{array}{r}\text { Alpha } \\
\text { MDA } \\
(\mathrm{uCi} / \mathrm{ml})\end{array}$ & $\begin{array}{r}\text { Corrected } \\
\text { Alpha result } \\
(\mathrm{uCi} / \mathrm{ml})\end{array}$ & $\begin{array}{r}\text { Alpha } \\
\text { Error } \\
\text { (Percent) }\end{array}$ & $\begin{array}{r}\text { Beta } \\
\mathrm{MDA} \\
\text { (uCi/ml) } \\
\end{array}$ & $\begin{array}{r}\text { Corrected } \\
\text { Beta result } \\
(\mathrm{uCi} / \mathrm{ml}) \\
\end{array}$ & $\begin{array}{r}\text { Beta } \\
\text { Error } \\
\text { (Percent) }\end{array}$ \\
\hline & & SV & 1 & 36.2 & $5.84 \mathrm{E}-07$ & & & $5.41 \mathrm{E}-07$ & & \\
\hline & & sV & 1 & 35.3 & 5.77 E-07 & & & $5.41 \mathrm{E}-07$ & & \\
\hline & & sV & 2 & 92.5 & $3.68 \mathrm{E}-07$ & & & $2.65 \mathrm{E}-07$ & & \\
\hline & & sv & 2 & 20.3 & $2.21 \mathrm{E}-07$ & & & $2.50 \mathrm{E}-07$ & & \\
\hline & & sv & 2 & 17.6 & $2.12 \mathrm{E}-07$ & & & 2.49E-07 & & \\
\hline & & sv & 2 & 19 & $2.17 \mathrm{E}-07$ & & & $2.50 \mathrm{E}-07$ & & \\
\hline & & sv & 2 & 25.5 & $2.52 \mathrm{E}-07$ & & & 2.69E-07 & & \\
\hline & & sv & 2 & 71.3 & 3.83E-07 & & & 2.77E 07 & & \\
\hline & & sv & 1 & 49.3 & 6.40E-07 & & & $7.79 \mathrm{E}-07$ & & \\
\hline & & sv & 2 & 32.1 & $2.50 \mathrm{E}-07$ & & & $3.76 \mathrm{E}-07$ & & \\
\hline & & sv & 2 & 0.9 & $1.62 \mathrm{E}-07$ & & & $3.47 \mathrm{E}-07$ & & \\
\hline & & sv & 2 & 1.2 & 1.63E-07 & & & $3.48 \mathrm{E}-07$ & & \\
\hline & & SV & 1 & 1.6 & $3.28 \mathrm{E}-07$ & & & $6.96 \mathrm{E}-07$ & & \\
\hline & & sv & 1 & 2.3 & $1.32 \mathrm{E}-08$ & & & $2.79 E-08$ & & \\
\hline & & sv & 1.67 & 51 & 3.96E-07 & & & $4.69 E-07$ & & \\
\hline 65705 & 0 & sv & 1 & 49.3 & $6.44495 \mathrm{E}-07$ & $3.87301 \mathrm{E}-06$ & 29.19275733 & $7.791 E-07$ & $2.0761 \mathrm{E}-05$ & 6.88679966 \\
\hline 65706 & 0 & sv & 2 & 32.1 & $2.52205 \mathrm{E}-07$ & $1.23122 \mathrm{E}-06$ & 32.34804847 & 3.757E-07 & $8.0165 \mathrm{E}-06$ & 7.48283722 \\
\hline 65707 & 0 & sv & 2 & 0.9 & $1.62288 \mathrm{E}-07$ & $6.0932 \mathrm{E}-07$ & 41.95699326 & $3.474 \mathrm{E}-07$ & $1.0061 \mathrm{E}-05$ & 6.14976034 \\
\hline 65708 & 0 & sv & 2 & 1.2 & $1.62976 \mathrm{E}-07$ & $4.47134 \mathrm{E}-07$ & 41.09055763 & $3.477 E-07$ & $1.6262 \mathrm{E}-06$ & 19.465765 \\
\hline 60385 & 0 & sV & 0.5 & 40.7 & $1.13984 \mathrm{E}-06$ & 3.25453E-06 & 41.2366412 & $1.531 \mathrm{E}-06$ & $1.0703 \mathrm{E}-05$ & 14.7366489 \\
\hline 60393 & 0 & sV & 0.5 & 45.6 & $1.22259 \mathrm{E}-06$ & 2.22565E-06 & 56.11594749 & 1.547E-06 & $8.7521 \mathrm{E}-06$ & 17.0875596 \\
\hline 60394 & 0 & sv & 0.5 & 31.2 & $9.96041 \mathrm{E}-07$ & 3.33819E-06 & 36.46112649 & $1.5 E-06$ & $9.3692 \mathrm{E}-06$ & 15.8628786 \\
\hline 60396 & 0 & sv & 0.25 & 33.2 & $2.04932 \mathrm{E}-06$ & 4.39255E-06 & 48.88939252 & 3.013E-06 & $1.4057 \mathrm{E}-05$ & 19.6058019 \\
\hline 60397 & 0 & sv & 0.0975 & 33.2 & 5.25467E-06 & 6.54865E-06 & 72.57424539 & 7.726E-06 & $2.9314 \mathrm{E}-05$ & 22.9279162 \\
\hline 60399 & 0 & sv & 0.1 & 22.3 & $4.3908 \mathrm{E}-06$ & $5.83379 \mathrm{E}-06$ & 69.63595381 & 7.345E-06 & $3.0632 \mathrm{E}-05$ & 21.2502886 \\
\hline 60400 & 0 & sV & 0.1 & 35.2 & $5.27056 \mathrm{E}-06$ & $1.01765 \mathrm{E}-06$ & 381.3792787 & 7.567E-06 & $3.1197 \mathrm{E}-05$ & 21.5035899 \\
\hline 60401 & 0 & sv & 0.1 & 16 & 4.01667E-06 & $6.19059 \mathrm{E}-06$ & 61.95792903 & 7.232E-06 & $2.953 \mathrm{E}-05$ & 21.5646566 \\
\hline 60403 & 0 & sv & 0.333333333 & 46.7 & 1.86295E-06 & $1.88723 \mathrm{E}-06$ & 83.91247155 & $2.325 \mathrm{E}-06$ & 7.072E-06 & 27.3472431 \\
\hline 60404 & 0 & sv & 0.5 & 23.1 & $8.88153 \mathrm{E}-07$ & $1.84956 \mathrm{E}-06$ & 48.97166407 & 1.472E-06 & $5.2587 \mathrm{E}-06$ & 23.9808668 \\
\hline 59704 & 0 & sv & 1.25 & 33.7 & $1.27908 E-07$ & 0.00100354 & 4.369808498 & 6.231E-07 & 0.00200419 & 2.77045403 \\
\hline Average & & & 1.196694444 & 30.016666667 & 1.12E-06 & & & 1. $65 \mathrm{E}-06$ & & \\
\hline Std. Dev: & & & 0.756630224 & 21.32749696 & $1.53452 \mathrm{E}-06$ & & & $2.418 \mathrm{E}-06$ & & \\
\hline Average: & & & & & 1116.922532 & $\mathrm{C}$ Ci/L & & 1647.2047 & $\mathrm{pC \textrm {Ci } / \mathrm { L }}$ & \\
\hline
\end{tabular}

Total 30 Samples

Notes:

Data Provided by Reggie Gaylord 9/21/06. 